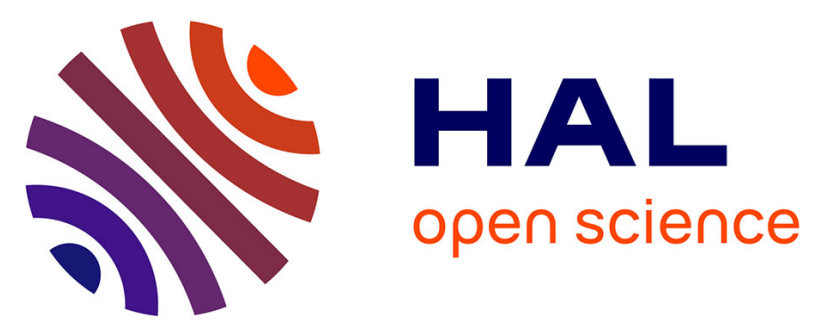

\title{
Exhumation of eclogite and blueschist (Cyclades, Greece): Pressure-temperature evolution determined by thermobarometry and garnet equilibrium modelling
} Valentin Laurent, Pierre Lanari, Inès Naïr, Romain Augier, Abdeltif Lahfid, Laurent Jolivet

\section{To cite this version:}

Valentin Laurent, Pierre Lanari, Inès Naïr, Romain Augier, Abdeltif Lahfid, et al.. Exhumation of eclogite and blueschist (Cyclades, Greece): Pressure-temperature evolution determined by thermobarometry and garnet equilibrium modelling. Journal of Metamorphic Geology, 2018, 36 (6), pp.769-798. 10.1111/jmg.12309 . insu-01744885

HAL Id: insu-01744885

https://hal-insu.archives-ouvertes.fr/insu-01744885

Submitted on 27 Mar 2018

HAL is a multi-disciplinary open access archive for the deposit and dissemination of scientific research documents, whether they are published or not. The documents may come from teaching and research institutions in France or abroad, or from public or private research centers.
L'archive ouverte pluridisciplinaire HAL, est destinée au dépôt et à la diffusion de documents scientifiques de niveau recherche, publiés ou non, émanant des établissements d'enseignement et de recherche français ou étrangers, des laboratoires publics ou privés. 
Exhumation of eclogite and blueschist (Cyclades, Greece):Pressure-temperature evolution determined by thermobarometry and garnet quilibrium modelling

Valentin LAURENT ${ }^{1,2,3}$, Pierre LANARI $^{4}$, Inès NAÏR, Romain AUGIER ${ }^{1,2,3}$, Abdeltif LAHFID $^{1,2,3}$, Laurent JOLIVET ${ }^{5}$

${ }^{1}$ Université d'Orléans, ISTO, UMR 7327, 45071, Orléans, France

${ }^{2}$ CNRS/INSU, ISTO, UMR 7327, 45071 Orléans, France

${ }^{3}$ BRGM, ISTO, UMR 7327, BP 36009, 45060 Orléans, France

${ }^{4}$ Institute of Geological Sciences, University of Bern, Baltzerstrasse 3, Bern CH-3012, Switzerland

${ }^{5}$ Sorbonne Université, UMR 7193 CNRS-UPMC, Institut des Sciences de la Terre Paris, F-75005

Paris, France

valentin.laurent@univ-orleans.fr (corresponding author)

\section{ABSTRACT}

High-pressure rocks such as eclogite and blueschist are metamorphic markers of paleosubduction zones, and their formation at high-pressure and low-temperature conditions is relatively well understood since it has been the focus of numerous petrological investigations in the past 40 years. The tectonic mechanisms controlling their exhumation back to the surface are, however, diverse, complex and still actively debated. Although the Cycladic Blueschist Unit (CBU, Greece) is among the best worldwide examples for the preservation of eclogite and blueschist, the proposed $P-T$ evolution followed by this unit within the Hellenic subduction zone is quite different from one study to another, hindering our comprehension of exhumation processes. In this study, we present an extensive petrological dataset that permits refinement of the shape of the $P$ - $T$ trajectory for different subunits of the CBU on Syros. High-resolution quantitative compositional mapping has been applied to support the thermobarometric investigations, which involve semi-empirical thermobarometry, garnet equilibrium modelling and $P$-T isochemical phase diagrams. The thermodynamic models highlight the powerful use of reactive bulk compositions approximated from local bulk compositions. The results were also

This article has been accepted for publication and undergone full peer review but has not been through the copyediting, typesetting, pagination and proofreading process, which may lead to differences between this version and the Version of Record. Please cite this article as doi: 10.1111/jmg. 12309

This article is protected by copyright. All rights reserved. 
combined with Raman Spectrometry of Carbonaceous Material (RSCM) to retrieve the metamorphic peak temperature distribution at the scale of the island. A major result of this study is the good agreement between all the independent thermobarometric methods, permitting reconstruction of the prograde and retrograde $P$ - $T$ trajectories. Garnet compositional zoning was used to retrieve prograde, peak and retrograde growth stages in line with the results of the $P$ - $T$ isochemical phase diagrams, RSCM temperature and peak pressure crystallization of the garnet-omphacite-phengite assemblage. Our results are consistent with previous thermobarometric estimates from other occurrences of CBU rocks (Tinos, Andros), suggesting a multi-stage exhumation process with (1) early syn-orogenic exhumation within the subduction channel, (2) isobaric heating at mid-crustal depths ( $\sim 10-12 \mathrm{kbar})$ following thermal re-equilibration of the lithosphere from a cold syn-orogenic regime in the subduction zone to a warmer post-orogenic regime in the back-arc domain, and (3) exhumation and cooling related to a post-orogenic phase of extension following slab retreat. Expanding to the general aspects of subduction zones, we suggest that such metamorphic evolution of HP-LT units should be regarded as a characteristic feature of exhumation driven by slab rollback.

\section{Keywords}

Subduction zone, Exhumation of eclogite and blueschist, Garnet equilibrium modelling, XMAPTOOLS, Slab rollback

\section{1 | INTRODUCTION}

Comprehension of the dynamic processes controlling the exhumation of high-pressure and lowtemperature (HP-LT) metamorphic rocks during subduction is partly based on the reconstruction of detailed Pressure-Temperature-time-deformation (P-T-t-d) paths of tectonic units that have undergone a complete burial-exhumation cycle. The Cycladic Blueschist Unit (CBU), cropping out in the Cycladic archipelago (Greece), is one of the best worldwide examples of a fossilized subduction channel. Syros Island, located in the central part of the Cyclades, is mainly composed of the CBU and is famous for its excellent preservation of HP-LT metamorphic rocks such as eclogites and blueschists. Consequently, this island has been the focus of petrological, structural and geochronological studies aimed at constraining the tectonometamorphic evolution of the CBU subduction complex (e.g. Cliff, Bond, Butler, \& Dixon, 2017; Keiter, Ballhaus, \& Tomaschek, 2011; Keiter, Piepjohn, Ballhaus, Lagos, \& Bode, 2004; Lagos et al., 2007; Laurent et al., 2016, 2017; Lister \& Forster, 2016; Philippon, Brun, \& Gueydan, 2011; Schumacher, Brady, Cheney, \& Tonnsen, 2008; Soukis \& Stöckli, 2013; Tomaschek, Kennedy, Villa, Lagos, \& Ballhaus, 2003; Trotet, Jolivet, \& Vidal, 2001a; Trotet, Vidal, \& Jolivet, 2001b). However, after a decade of investigations, the tectonometamorphic evolution of the CBU of Syros is still actively debated, as attested by the different shapes of $P-T$ paths proposed in the literature from burial to exhumation (Figure 1). For example, Trotet et al. (2001b) used a multi-equilibrium approach with the TWEEQU software (Berman, 1991) to characterize the $P-T$ paths followed by eclogite-, blueschist- and greenschist-facies metamorphic rocks from different tectonic subunits on Syros. Their results lead to the conclusion that, irrespective of the intensity of retrogression, the different units have all undergone the same metamorphic peak conditions around $20 \mathrm{kbar}$ and $550{ }^{\circ} \mathrm{C}$ but have followed distinct exhumation evolutions after peak metamorphism (Figure 1a). In this scenario, the preservation of eclogitic parageneses at the top of the lithological pile of Syros is explained by cooling during exhumation. A stronger retrogression under greenschist-facies conditions is observed further down and is associated 
with an isothermal decompression up to mid-crustal conditions (Figure 1a). Following this model, the CBU has been progressively exhumed by a continuum of accretion at the base of the orogenic wedge

The second scenario, from Schumacher et al. (2008), is based on calculated mineral equilibria in glaucophane-bearing marbles of the northern part of the island. Considering assemblages and mineral compositions of the studied marbles, narrow constraints on the $P-T$ evolution of the CBU with peak-metamorphic conditions of about $15-16 \mathrm{kbar}$ and $500{ }^{\circ} \mathrm{C}$ were obtained (Figure $1 \mathrm{~b}$ ). According to this model, the CBU has followed a single $P-T$ path implying a rigid block exhumation.

Finally, Lister and Forster (2016) have proposed a rather more complex $P-T$ scenario for the CBU on Syros (Figure 1c). In this yo-yo tectonic model, the major shear zones are successively reactivated in opposite motions after the first pressure peak, the subducted rocks being exhumed, buried and exhumed again along a $P-T$ loop in the early exhumation part of the $P-T$ path. However, such loop still remains an unconstrained conceptual model, neither by thermobarometric data (grey ellipses in Figure 1c) nor by petrological observations of multiple generations of mineral overgrowths (e.g. Rubatto et al., 2011).

These studies lead to contrasted interpretations of the $P-T$ evolution of the CBU on Syros and thus significantly different exhumation processes and geodynamic scenarios. As long as such discrepancies are not addressed, the deep processes and long-term evolution of HP-LT units in the subduction zone and exhumation processes will remain poorly understood.

In this study, we present an extensive petrological dataset that permits to refine the $P-T$ trajectory of several subunits of the CBU on Syros previously reported in Laurent et al. (2016). As discussed above, detailed petrological observations are required to support the results of $P-T$ modelling which have serious implication on tectonic scenarios. It is especially important to retrieve how many metamorphic stages are preserved in the mineral record and to understand chemical zoning of minerals in a textural context (e.g. Airaghi, Lanari, de Sigoyer, \& Guillot, 2017; Fiannacca, Pò, Ortolano, Cirrincione, \& Pezzino, 2012; Giuntoli, Lanari, \& Engi, 2018; Kohn \& Spear, 2000; Tedeschi et al., 2017; Vidal et al., 2006). This is the main reason why, for each sample, highresolution quantitative compositional maps have been obtained by electron probe micro-analyser (EPMA) and processed using the software XMAPToOLS (Lanari et al., 2014; Lanari, Vho, Bovay, Airaghi, \& Centrella, 2018). This detailed petrological dataset was used to perform semi-empirical thermobarometry, garnet equilibrium modelling (GRTMOD; Lanari, Giuntoli, Loury, Burn, \& Engi, 2017), $P-T$ isochemical phase diagrams that are combined with Raman Spectrometry of Carbonaceous Material (RSCM) to refine the shape of both prograde and retrograde $P-T$ trajectories. The chemical maps provide both a micro-textural context to interpret chemical zoning and to quantitatively estimate local bulk compositions, which can be used as input for the thermodynamic models (Lanari \& Engi, 2017; Marmo, Clarke, \& Powell, 2002). This original approach shows that the micro-mapping technique combined with iterative thermodynamic modelling and RSCM thermometry provide efficient tools to reconstruct $P$ - $T$ paths in blueschists and eclogites. 


\section{2 | GEOLOGICAL CONTEXT}

\subsection{Aegean domain}

The Aegean domain corresponds to a collapsed segment of the Hellenic belt above a north-plunging subduction zone (Figure 2; Jolivet, Daniel, Truffert, \& Goffé, 1994; Le Pichon \& Angelier, 1981; Ring, Glodny, Will, \& Thomson, 2010). The tectonometamorphic evolution of this domain is traditionally described in two main stages (Figure 2; Jolivet \& Brun, 2010; Ring et al., 2010). First, the late Cretaceous-Eocene convergence between Africa and Eurasia plates led to the formation of the Hellenides-Taurides belt. During this episode, a series of oceanic and continental nappes entered the subduction zone and were thrust on top of each other in an overall HP-LT metamorphic context (Bonneau \& Kienast, 1982). Then, inception and acceleration of African slab retreat from 35-30 Ma led to southward migration of the subduction front, crustal collapse of the belt in the back-arc domain and extensional reworking of the nappe stack (Jolivet, Rimmelé, Oberhänsli, Goffé, \& Candan, 2004; Jolivet et al., 2013; Le Pichon \& Angelier, 1981; Lister, Banga, \& Feenstra, 1984). Extension in the back-arc domain was characterized by a distributed deformation oriented N-S over a wide region covering the entire Aegean Sea, part of western Anatolia and the Rhodope Massif in the north (Gautier \& Brun, 1994; Jolivet \& Brun, 2010; Jolivet \& Patriat, 1999; Ring et al., 2010; Urai, Schuiling, \& Jansen, 1990). Extensional tectonics were also characterized by more localized deformation with the development of large-scale detachments and metamorphic core complexes (MCCs) in which the exhumation of HP-LT units was completed in a low-pressure and hightemperature (LP-HT) environment (Figure 2; Gautier, Brun, \& Jolivet, 1993; Jolivet \& Patriat, 1999; Lister et al., 1984; Urai et al., 1990).

The Cycladic Archipelago is located in the centre of the Aegean domain and corresponds to the deepest exhumed parts of the Hellenides-Taurides belt (Figure 2). In this archipelago, the Cycladic Blueschist Unit, belonging to the Pindos oceanic domain (Bonneau, 1984; Bonneau \& Kienast, 1982), reached peak-pressure conditions during the formation of the Hellenides at 53-48 Ma (Figure 2; Lagos et al,. 2007; Laurent et al., 2017; Lister \& Forster, 2016; Tomaschek et al., 2003; Uunk, Brouwer, ter Voorde, \& Wijbrans, 2018). This HP-LT metamorphic unit was exhumed during the Eocene within the subduction channel between a top-to-the south thrust at the base and top-to-the east/northeast synorogenic detachment at the top, the Vari Detachment (Figure 2; Augier, Jolivet, Gadenne, Lahfid, \& Driussi, 2015; Brun \& Faccenna, 2008; Huet, Labrousse, \& Jolivet, 2009; Jolivet, Faccenna, Goffé, Burov, \& Agard, 2003; Laurent et al., 2016; Ring et al., 2007, 2010). In the Cyclades, regional-scale detachments such as the North Cycladic Detachment System (NCDS), the Naxos-Paros Detachment (NPD) or the West Cycladic Detachment System (WCDS) have accommodated back-arc extension (Figure 2; Grasemann, Schneider, Stöckli, \& Iglseder, 2012; Jolivet et al., 2010). Eclogite and blueschist of the CBU are best preserved on Syros Island, where the synorogenic Vari Detachment is exposed (Laurent et al., 2016; Soukis \& Stöckli, 2013; Trotet et al., 2001a).

\section{2 | Geology of Syros}

Located in the Cycladic Archipelago (Figure 2), Syros is mainly composed of metasedimentary and metabasite from the CBU. To the SE of the island, a large-scale klippe of Pelagonian affinity, locally referred as the Vari Unit, is also exposed, limited by the Vari detachment (Figure 3; e.g. Soukis \& Stöckli, 2013). Laurent et al. (2016) have subdivided the stack of the CBU on Syros in three subunits, 
delimited by extensional top-to-the east shear zones and characterized by their lithology and predominant metamorphic facies, which are from bottom to top as follows (Figure 3): (1) The Posidonia Subunit is composed of the structurally lower felsic gneiss of Komito overlain by albitic micaschists with intercalated, quite rare, boudins of metabasite and thin marble layers. This subunit has been pervasively overprinted in the greenschist-facies, except in few places where occurrences of blueschist- and eclogite-facies parageneses are seldom observed, (2) The Chroussa Subunit is composed of a lithostratigraphic sequence of alternating micaschists, thick marble layers and metabasites. This subunit is in part overprinted in the greenschist-facies while other places show well preserved eclogite- and blueschist-facies parageneses, (3) The Kampos Subunit is mainly composed of a tectonic mélange of metabasites wrapped in serpentinites and minor metasedimentary rocks. Within this subunit, eclogite- and blueschist-facies parageneses are spectacularly preserved, apparently escaping significant retrogression in the greenschist facies.

Eclogite parageneses are therefore recognized within all three subunits (Laurent et al., 2016), implying that despite their entirely different degrees of retrogression, these three subunits have undergone similar HP-LT metamorphic and peak $P-T$ conditions (Trotet et al., 2001b). Finally, structurally positioned above the CBU (Keiter et al., 2004, 2011; Soukis \& Stöckli, 2013; Trotet et al., 2001a), the Vari Unit is formed by a greenschist mylonitic unit overlain by the orthogneiss of Vari intruding amphibolite-facies metabasite. High-pressure imprinting is not recognized and apparently lacking as in other outcrops of Pelagonian rocks (Laurent et al., 2016; Soukis \& Stöckli, 2013).

\section{3 | METHODS}

\section{1 | EPMA compositional mapping}

$\mathrm{X}$-ray maps have been acquired to measure the compositional variability of the studied minerals at the local scale (from half a $\mathrm{mm}$ to a few $\mu \mathrm{m}$ ) and to investigate the relationships between compositional zoning and microstructures. This technique has proved to be efficient in the characterization of compositional zoning related to $P-T$ changes (Kohn \& Spear, 2000; Lanari et al., 2012, 2013; Loury, Rolland, Cenki-Tok, Lanari, \& Guillot, 2015). A JEOL JXA-8230 instrument was used at ISTerre (University of Grenoble-Alpes, France) to acquire X-ray compositional maps and spot analyses required for the analytical standardization of the maps (de Andrade, Vidal, Lewin, O'brien, \& Agard, 2006). Analytical conditions for mapping were $15 \mathrm{keV}$ accelerating voltage, $100 \mathrm{nA}$ specimen current and $15 \mathrm{keV}$ accelerating voltage and $12 \mathrm{nA}$ specimen current for spot analyses. Compositional mapping was carried out with dwell time of $200 \mathrm{~ms}$ and a step size (corresponding to the pixel size in the final images) of $2 \mu \mathrm{m}$.

The X-ray compositional maps were processed using the program XMAPTOOLS 2.2.1 (Lanari et al., 2014, 2018). The classification assigned each pixel to a mineral, which was then standardized using the high-resolution spot analyses as internal standards. Each intensity map was converted during this step to a map of oxide weight-percentage composition. Local bulk compositions were generated from the oxide weight-percentage maps by averaging pixels with a density correction (Lanari \& Engi, 2017). Finally, the structural formula was calculated for each pixel of the mapped area on the basis of 12 anhydrous oxygen for garnet, 11 for white mica, 12.5 for epidote, 6 for clinopyroxene, 14 for chlorite and 8 for feldspar. 


\section{2 | Bulk rock composition and reactive bulk composition}

Bulk rock composition of each sample was measured at the CRPG (Nancy, France) where major element concentrations were obtained by ICP-OES analyses. Results are reported in Table 1. In the literature, most of the P-T isochemical phase diagrams (or pseudosections) rely on the measured bulk rock composition as an approximation of the reactive (or effective) bulk composition, which is defined as the composition of the equilibration volume at a given stage of the rock history. However, it has been demonstrated that this approximation can lead to erroneous $P-T$ estimates if the sample contains zoned minerals (see Lanari \& Engi, 2017 for a recent review). In such cases it is critical to restrict the investigation to a more reduced scale where chemical equilibrium may have been established. As the diffusion rates of the major cations in the intergranular medium are largely unknown, a qualitative approximation of the size of the equilibration volume is required.

In this study, all the equilibrium models involving Gibbs free energy minimizations were computed using as reference both (1) the bulk rock composition measured by ICP-OES and (2) a local bulk composition derived from thin-section analysis and compositional maps. In both cases, the reference composition is used as the first reactive bulk composition, i.e. to estimate the $P-T$ condition of the first stage. Then, the reactive bulk composition evolves along the $P$ - $T$ trajectory because of garnet fractionation (Konrad-Schmolke, O'Brien, de Capitani, \& Carswell, 2008; Moynihan \& Pattison, 2013; Spear, 1988).

The local bulk compositions were calculated based on the mode of the petro-textural domains (porphyroblasts with their inclusions, mineral-matrix, domains showing late retrogression) observed within the thin section and their local bulk compositions determined with XMAPTOOLS; this is somewhat equivalent to what has been done in other studies (Loury et al., 2015; Marmo et al. 2002; Warren \& Waters, 2006). Mineral abundances were estimated by thin-section optical image analysis. The composition of each local domain is evaluated from the compositional map using XMAPTOOLS and a density correction function.

\section{3 | Thermometric/thermobarometric methods}

\subsection{1 | Raman Spectrometry of Carbonaceous Material (RSCM) geothermometry}

The RSCM method is an empirical geothermometric approach based on the quantification of the degree of organization of carbonaceous material (CM) reached during metamorphism (Beyssac, Goffé, Chopin, \& Rouzaud, 2002a). Due to the irreversible character of graphitization, CM structure is not affected by retrogression reactions and allows metamorphic peak temperature (RSCM-T) to be calculated, using an area ratio (R2 ratio) of different peaks of the Raman spectra (Beyssac et al., 2002a). The reader interested in the graphitization process during HP-LT metamorphism in terms of physico-chemical transformation of CM is referred to Beyssac, Rouzaud, Goffe, Brunet, and Chopin (2002b). RSCM-T are determined with a calibration-attached accuracy of $\pm 50{ }^{\circ} \mathrm{C}$ in the range 330$640{ }^{\circ} \mathrm{C}$ (Beyssac et al., 2002a). Relative uncertainties on RSCM-T obtained from samples selected within the same section are however much smaller and bracketed to $10-15{ }^{\circ} \mathrm{C}$ (e.g. Augier et al., 2015; Gabalda, Beyssac, Jolivet, Agard, \& Chopin, 2009; Brovarone et al., 2013). Raman spectra 
were obtained using the Renishaw inVia Reflex system (BRGM-ISTO, Orléans). RSCM analyses were conducted on thin sections prepared on CM-rich metasedimentary rocks cut in the structural X-Z plane. To avoid defects on the CM related to thin-section preparation, analyses were all performed below the surface of the section by focusing the laser beam beneath dominantly quartz and calcite. Between 11 and 25 spectra were recorded in order to bring out the inner structural heterogeneity of CM within samples. Internal dispersion of RSCM-T presents generally unimodal temperature distributions with quite low dispersion. The investigated samples are $19 \mathrm{CM}$-bearing marble and metapelite samples collected within the three subunits composing the CBU on Syros, ensuring the determination of the large-scale thermal structure of this island (Figure 3).

\subsection{2 | Thermodynamic modelling}

The $P-T$ evolution of the metamorphic rocks was reconstructed based on forward thermodynamic models. As garnet growth strongly fractionates the reactive bulk composition, the program GRTMOD (Lanari et al. 2017) was used to retrieve the $P-T$ information stored in garnet compositional zoning. GRTMOD searches the optimal $P-T$ conditions for the composition of each successive growth zone using a fractional crystallization model and with possible resorption of the previous zones (a complete description is provided in Lanari et al. 2017). As the maximum temperature reached by the sample is $\sim 550{ }^{\circ} \mathrm{C}$ (see below), intragranular diffusion is not expected to have significantly altered the compositional zoning of the large porphyroblast that is interpreted as growth zoning (Caddick, Konopásek, \& Thompson, 2010). As the compositions of the co-existing phases such as omphacite and phengite are less sensitive to changes in the reactive bulk composition (e.g. Airaghi et al. 2017 for phengite), the bulk rock composition or local bulk composition was used to generate the $P$ - $T$ diagrams showing mineral isopleths. The Gibbs free energy minimizations and the isochemical phase diagrams were computed using the program Theriak-Domino (de Capitani \& Brown, 1987; de Capitani \& Petrakakis, 2010) in the chemical system $( \pm \mathrm{MnO})-\mathrm{Na}_{2} \mathrm{O}-\mathrm{CaO}-\mathrm{K}_{2} \mathrm{O}-\mathrm{FeO}-\mathrm{Fe}_{2} \mathrm{O}_{3}-\mathrm{MgO}-\mathrm{Al}_{2} \mathrm{O}_{3}-\mathrm{SiO}_{2}-$ $\mathrm{TiO}_{2}-\mathrm{H}_{2} \mathrm{O}$. The internally consistent thermodynamic database JUN92.bs (Berman, 1988 and subsequent updates) was used for modelling. A comparison of the results obtained with other thermodynamic databases is shown in Figure S1. Four models were systematically derived for each sample, using the bulk rock composition (WR) and the local bulk compositions (LB), in both either considering or not $\mathrm{MnO}$.

\section{4 | PETROGRAPHY AND MINERAL CHEMISTRY}

A petrographic description of analysed samples based on the results of compositional mapping is presented here. Four samples, characteristic of the entire CBU from top to base, were selected for this study (from a collection of 138). Two were collected in the Kampos Subunit to determine burial and peak-pressure conditions. Additionally, one sample was selected in Chroussa Subunit to characterize the transition from blueschist- to greenschist-facies $P-T$ conditions and one sample preserving HP parageneses was collected from Posidonia Subunit to compare the maximum pressure conditions recorded in this subunit and in the Kampos Subunit. Typical textures and mineral assemblages of the four samples are shown in Figure 4. All mineral abbreviations are after Whitney and Evans (2010). 


\section{1 | Sample SY1401 (Kampos Subunit)}

\subsection{1 | Outcrop and sample description}

The studied outcrop is located south of Syros airport and shows a $50 \mathrm{~m}$-long retrogression gradient from well-preserved HP rocks, including very fresh eclogite, to strongly overprinted HP rocks in the greenschist-facies (Figures 3 and 5). This apparent metamorphic transition is accompanied by an increasing gradient of deformation toward the more retrogressed rocks (Figure 5a). This outcrop corresponds to the contact zone between the Kampos and Chroussa subunits, which is interpreted as an extensional top-to-the east shear zone, namely the Kastri Shear Zone (see Laurent et al., 2016 for details).

Well-preserved eclogite shows a weak deformation and still exhibits the original structure of a pillow-lava breccia (Figure 5b-d). While only a slight foliation is observed, a lineation oriented N90 ${ }^{\circ} \mathrm{E}$ is marked by intense stretching (Figure $5 \mathrm{c}$ ). Markers of asymmetric ductile deformation, such as shear bands, are rare and visible only at the microscopic scale, showing an incipient top-to-the east sense of shear (Figure 6a).

The eclogitic metapillow-lava breccia studied here is typical of rocks from the Kampos Subunit with only weak subsequent overprinting. In this sense, this sample appears as one of the best candidates to determine peak-pressure conditions and possibly prograde $P-T$ conditions of the CBU on Syros. The metamorphic assemblage of this sample includes garnet, white mica, epidote, clinopyroxene and less abundant quartz, albite, apatite, rutile and sphene (Figures 4 and 6). Garnet occurs as $0.5-1.5 \mathrm{~mm}$ porphyroblasts and contains inclusions of epidote, white mica, clinopyroxene, albite and quartz (Figures 4 and 6).

\subsection{2 | Petrography}

Chemical composition mapping of 400,000 pixels covers an area of $1600 * 1000 \mu \mathrm{m}$ and was acquired around a $1.3 \mathrm{~mm}$ diameter garnet showing a large diversity of mineral inclusions (Figure 6). This garnet is comprised within an eclogitic matrix and surrounded by a pressure shadow, dividing the $\mathrm{X}$ ray map into three distinct petro-textural domains (Figure 6d). The eclogitic matrix is mainly composed of omphacite, epidote and white mica with less abundant quartz, apatite and sphene (Figure $6 \mathrm{~b}, \mathrm{c})$. The pressure-shadow on the garnet is mainly composed of white mica associated with albite (Figure 6).

Compositional zoning is observed in garnet porphyroblasts with, from core to rim, a decrease of almandine and spessartine $\left(\mathrm{XAlm}_{0.65 \rightarrow 0.57}\right.$ and $\left.\mathrm{XSps}_{0.045 \rightarrow 0.02}\right)$ and an increase of grossular and pyrope (Figure 7; $\mathrm{XGrs}_{0.24 \rightarrow 0.30}$ and $\mathrm{XPrp}_{0.07 \rightarrow 0.11}$ ). The rim composition of garnet is also affected by the presence of phengite inclusions with a relatively higher grossular, pyrope and spessartine content that evidences garnet re-equilibration around them (Figure 7). 
The composition of white mica shows a more complex pattern with four distinct compositional groups based on the $\mathrm{Si}$ and $\mathrm{Na}$ contents (Figure 7). Within the omphacitic matrix and in the pressure-shadow, phengite shows a strong increase in celadonite from core to rim and at the contact with the garnet porphyroblast (Figure 7; phengite 1: $\mathrm{XCel}_{=0.35-0.45}$ and phengite 2: $\mathrm{XCel}_{=0.45-}$ 0.65). Phengite 1 is also observed as an inclusion in the garnet rim. In contrast, Si-poor phengite 3 and phengite-paragonite mixing compositions are only observed as inclusions in garnet cores (Figure 7).

In the eclogitic matrix, clinopyroxene corresponds to omphacite, with some grains showing a compositional zoning marked by an increase of the jadeite-content from core to rim (Al_M in Figure $7 ; \mathrm{XJd}_{0.36 \rightarrow 0.46}$ ). In contrast, inclusions of clinopyroxene observed in the core of the garnet have lower jadeite content $\left(\mathrm{XJd}_{=0.30-0.35}\right)$ similar to the core of some grains of the matrix (Figure 7). Two distinct compositions of epidote are observed in the map with higher zoisite-content for the grains included into the garnet $\left(\mathrm{XZo}_{=0.60-0.75}\right)$ than those of the omphacitic matrix $\left(\mathrm{XZo}_{=0.30-0.45}\right)$. Plagioclase has homogeneous and nearly pure albitic composition $\left(\mathrm{XAb}_{=0.99}\right)$ and is found both included in the core of the garnet and in the pressure-shadow where it has grown into the cleavage of phengite and around a few grains of remnant omphacite and quartz. Finally, less abundant rutile is observed in some garnet rims, while apatite and sphene accessory minerals are only observed in the omphacitic matrix (Figure 6).

\subsection{3 | Petrographic interpretations}

The compositional zoning preserved in garnet, phengite and omphacite can be used in a qualitative way to reconstruct the $P-T$ history of this sample. Several lines of evidence suggest the prograde growth of garnet under increasing pressure conditions, (1) plagioclase inclusions are only observed in the core of garnet, suggesting that the transformation of plagioclase into omphacite was not complete at the initiation of garnet growth, (2) the chemical composition of omphacite and phengite inclusions in the core of garnet have respectively lower XJd and XCel content than inclusions in the rim, which again suggests an increase in pressure during garnet growth, (3) the compositional zoning in both omphacite and phengite grains in the matrix shows a similar trend (e.g. increase in XJd and XCel, respectively) and also supports the record of a prograde trajectory. The only evidence of retrogression observed in this sample is the presence of albite in the pressure shadow. Albite occurs only in omphacite-poor domains and is interpreted as a late feature, formed at the expense of omphacite and quartz. This interpretation is supported by observations of remnant quartz and omphacite grains in the pressure shadow that are systematically surrounded by newly grown albite (Figure 6).

\section{2 | Sample SY1460 (Kampos Subunit)}

\subsubsection{Outcrop and sample description}

This sample was collected in the Kampos Subunit on the south coast of Syros, and is structurally positioned just below the Vari Detachment (Figure 3; Laurent et al., 2016; Soukis \& Stöckli, 2013; Trotet et al., 2001a). This outcrop is composed of metabasite preserving eclogite- and blueschistfacies parageneses that are ductilely sheared with syn-blueschist top-to-the east kinematics (Laurent et al., 2016). This sample corresponds to a foliated and stretched boudin of eclogite hosted in blueschist- 
facies rocks. Textural analysis shows that a matrix composed of omphacite and white mica with minor calcite, sphene and epidote formed $\sim 95$ vol\% of the sample volume and comprised a few large garnet (0.5-1 mm) and glaucophane (5-10 mm) crystals (Figures 4 and 8).

\subsection{2 | Petrography}

The X-ray map of 204,750 pixels covering an area of $910 * 900 \mu \mathrm{m}$ was acquired around a $0.9 \mathrm{~mm}$ diameter garnet of almandine type showing inclusions of clinopyroxene and rutile and a core to rim zonation (Figure 9). Almandine content decreases toward the rim $\left(\mathrm{XAlm}_{0.66 \rightarrow 0.59}\right)$ while grossular and pyrope content show a general increase $\left(\mathrm{XGrs}_{0.24 \rightarrow 0.28}\right.$ and $\left.\mathrm{XPrp}_{0.06 \rightarrow 0.09}\right)$. The spessartine content displays a more complex, oscillatory zoning pattern $\left(\mathrm{XSps}_{0.042 \rightarrow 0.058}\right.$; Figure 9).

Two compositional groups of white mica are observed in this sample (phengite 1 and 2, Figure 9). Phengite 1 is characterized by a relatively high-celadonite $\left(\mathrm{XCel}_{=0.60-0.73}\right)$ and occurs as fine grain cores surrounded by phengite 2 rims, which has lower celadonite $\left(\mathrm{XCel}_{=0.45-0.53}\right)$. Most of the matrix grains show phengite 2 composition (Figure 9). Omphacite can be divided into two compositional groups. Omphacite 1 has lower jadeite and higher diopside content $\left(\mathrm{XJd}_{=0.36-0.40}\right.$, $\left.\mathrm{XDi}_{=0.35-0.38}\right)$ than omphacite $2\left(\mathrm{XJd}_{=0.46-0.54}, \mathrm{XDi}_{=0.27-0.32}\right)$, and is observed in the core of the omphacite 2 in both matrix and garnet (Figure 9). The composition of glaucophane is homogeneous $\left(\mathrm{XGln}_{=0.95-}\right.$ 0.99) and only a few epidote grains are observed in the matrix with a few allanitic cores (Figure 8).

\subsection{3 $\mid$ Petrographic interpretations}

Similar to sample SY1401, prograde $P-T$ conditions are suggested by the compositional zoning preserved in garnet and omphacite. However, in this case the compositional zoning of phengite shows a different record, with lower XCel contents observed at the rim of garnet grains. This feature suggests later re-equilibration of phengite grains in the mineral matrix under lower pressure conditions and possibly higher temperatures.

Oscillatory zoning in garnet may reflect variations in the garnet-forming reaction or transportcontrolled growth (Kohn, 2014). It is an open question if the assumption of chemical equilibrium used in the thermodynamic models is valid or not for this specific case. It is important to note here that only $\mathrm{Mn}$ is affected by oscillatory zoning and to a relatively low extent (between $\mathrm{XSps}_{0.045}$ and $\mathrm{XSps}_{0.06}$ ) that would not necessarily be detected without using quantitative maps. If the equilibrium volume for $\mathrm{Mn}$ was smaller than the equilibration volume of the other major elements when garnet grew, then the Mn component needs to be excluded from the thermodynamic computations. 


\section{3 | Sample SY1407 (Chroussa Subunit)}

\subsection{1 | Outcrop and sample description}

The outcrop is located in the southeast of the island within the Chroussa Subunit (Figure 3). It is mainly composed of albite-epidote-blueschist-facies (AEBS metamorphic facies of Evans, 1990) metasedimentary rock, hosting metabasite boudins in which eclogite and blueschist parageneses are preserved. This sample corresponds to an AEBS-facies metasedimentary rock showing a clear lineation oriented $\mathrm{N} 70{ }^{\circ} \mathrm{E}$ marked by the stretching of glaucophane and albite. Textural analysis shows that this sample is composed of a matrix of quartz, white mica, glaucophane, albite and epidote with minor chlorite, rutile, and apatite in which large garnet occurs (0.5-1.5 mm, Figures 4 and 10).

\subsection{2 | Petrography}

The compositional mapping of 288,750 pixels covers an area of $1100 * 1050 \mu \mathrm{m}$ and was acquired around a $1.5 \mathrm{~mm}$ diameter garnet comprising mainly quartz inclusions (Figure 10). The composition of the garnet porphyroblast changes from core to rim (Figure 11). The core shows comparatively low almandine, spessartine and pyrope $\left(\mathrm{XAlm}_{=0.61-0.62}, \mathrm{XSps}_{=0.075-0.085}, \mathrm{XPrp}_{=0.038-0.04}\right)$ and high grossular $\left(\mathrm{XGrs}_{=0.24-0.26}\right)$. A decrease of both almandine and spessartine is observed through the mantle to rim $\left(\mathrm{XAlm}_{0.66 \rightarrow 0.59}, \mathrm{XSps}_{=0.12 \rightarrow 0.04}\right)$ coupled to an increase of pyrope and grossular $\left(\mathrm{XPrp}_{0.046 \rightarrow 0.061}\right.$, $\mathrm{XGrs}_{0.17 \rightarrow 0.28}$ ). The composition of white mica corresponds in a large majority to paragonite, with only a few phengite grains observed as inclusions in garnet and single grains in the mineral-matrix (Figure 11). Glaucophane grains, observed in the matrix, show textural equilibrium relationships with albite and epidote (Figure 10).

\subsection{3 $\mid$ Petrographic interpretations}

In this sample, compositional zoning is only observed in garnet but with a more complex pattern than in samples SY1401 and SY1460. The texture and compositional zoning of the garnet core differs from the mantle and rim and is interpreted as a relict preserved from either the protolith or as a first growth stage followed by intense resorption. As rocks of the CBU are all characterized by a single metamorphic history, the garnet core is more likely the result of a first stage of garnet growth followed by intense garnet resorption before a new stage of garnet growth. The lack of index mineral inclusions in the core (most of the inclusions are quartz) does not allow the coexisting assemblage to be determined. The presence of albite inclusions in the garnet rim suggests that the second growth episode took place at moderate pressure conditions, possibly during exhumation. This is consistent with fine-grained phengite inclusions in the garnet rim that show intermediate $\mathrm{Si}$-content and with the presence of glaucophane, epidote and albite in textural equilibrium in the matrix. Similar features have been interpreted as strong evidence of retrogression in the albite-epidote-blueschist facies (Evans, 1990). Following these observations, compositional zoning of the garnet in SY1407 may be interpreted as a first event of garnet growth, followed by an intense stage of resorption and a second growth episode that took place after partial exhumation of the rock. 


\section{4 | Sample SY1418 (Posidonia Subunit)}

\subsubsection{Outcrop and sample description}

This sample was collected in the SW of Syros, in the Posidonia Subunit, where few metabasite lenses occur within the gneiss of Komito (Figure 3). Metabasite appears pervasively retrograded under greenschist-facies conditions. However, Laurent et al. (2016) have shown that within metre-scale metabasite boudins, HP relicts are preserved with the occurrence of eclogite- and blueschist-facies parageneses. Sample SY1418 corresponds to one of these preserved HP metabasite occurrences of the Posidonia Subunit and has been selected to estimate maximum $P-T$ conditions undergone by the Posidonia Subunit. Textural analysis shows that this sample is formed by a matrix of fine-grained glaucophane and omphacite with minor rutile, Fe-oxide, white mica, epidote and albite hosting porphyroblasts of garnet, glaucophane, quartz, calcite and chlorite (Figures 4 and 12). Pressure shadows are composed of quartz, phengite, epidote and glaucophane with minor albite and represent 10 vol\% of the sample (Figure 12).

\subsection{2 | Petrography}

The compositional mapping of 160,801 pixels covers an area of $802 * 802 \mu \mathrm{m}$ and was acquired around a $0.6 \mathrm{~mm}$ diameter garnet showing numerous inclusions of quartz, epidote and Fe-oxide (Figure 12). This garnet is compositionally zoned with increasing almandine and pyrope $\left(\mathrm{XAlm}_{0.62 \rightarrow 0.70}, \quad \mathrm{XPrp}_{0.038 \rightarrow 0.09}\right)$ and decreasing spessartine and grossular toward the rim $\left(\mathrm{XSps}_{0.08 \rightarrow 0.004}, \mathrm{XGrs}_{0.24 \rightarrow 0.17}\right.$; Figure 13). The composition of white mica is homogeneous and corresponds to phengite $(\mathrm{XCel}=0.40$ ). The minor presence of omphacite is also observed as fine grains in the main glaucophane matrix (Figure 12).

\subsection{3 | Petrographic interpretations}

Omphacite compositions suggest that this sample has reached eclogite-facies conditions. Then, it has recorded a strong retrogression as attested by the practically complete destabilisation of omphacite (+quartz) into albite. The chlorite-albite assemblage is characteristic of low-pressure conditions. Compositional zoning is again restricted to garnet and does not provide a clear picture of the recorded $P-T$ history. However, the higher proportion of garnet in this sample ( 35 vol\%; Figure 12) suggests crystallization under HP conditions with absence of significant resorption.

\section{5 | THERMOBAROMETRY RESULTS}

\section{1 | RSCM geothermometry}

RSCM geothermometry has been applied to 19 samples distributed all over the island (Figure 3). Detailed results, including R2 ratio, number of spectra, RSCM-T and standard deviation are presented in Table 2. In addition, measured RSCM temperatures are all reported on the metamorphic map of Syros (Figure 3). Maximum temperatures recorded in the three subunits of Syros yielded very similar RSCM-T. This temperature is then compared with peak temperature estimates obtained using thermodynamic modelling. 
Results show that RSCM-T range from 489 to $564{ }^{\circ} \mathrm{C}$ in the Posidonia Subunit, 485 to $581{ }^{\circ} \mathrm{C}$ in the Chroussa Subunit and 510 to $561{ }^{\circ} \mathrm{C}$ in the Kampos Subunit. On average, RSCM-T are equivalent within error in each subunit with $537 \pm 20^{\circ} \mathrm{C}$ in the Posidonia Subunit, $540 \pm 19{ }^{\circ} \mathrm{C}$ in the Chroussa Subunit and $530 \pm 17{ }^{\circ} \mathrm{C}$ in the Kampos Subunit (Table 2). Moreover, the maximum RSCM-T measured in each subunit is also equivalent within error, showing that these three subunits have experienced quite similar peak temperatures during their metamorphic history. However, the RSCM-T measured within a single subunit varies up to $100{ }^{\circ} \mathrm{C}$, as observed in the Posidonia and Chroussa subunits (Table 2). There is no apparent correlation between the internal RSCM-T variations and the structural positions of the sample. In some cases, varying RSCM-T were estimated in samples collected at the same structural level, within a single and consistent lithology (Figure 3). The significance of partial discrepancies in the temperatures is beyond the scope of this study. Such variations are generally explained by the presence of an inherited component of CM (Beyssac et al., 2002a) or to the concentration of structural defects caused by pervasive deformation (see Aoya et al., 2010 for further discussions).

\section{$5.2 \mid$ Empirical thermobarometry}

The garnet-omphacite thermometer of Ravna (2000) was used to estimate the temperature of garnet and co-existing omphacite, whereas the pressure information was extracted from the assemblage garnet-omphacite-phengite (Waters \& Martin, 1996). The $P-T$ maps have been calculated in XMAPToOLS for samples SY1401 and SY1460, following the strategy described in Lanari et al. $(2013,2014)$.

In sample SY1401, petrographic observations suggest that garnet records prograde to peakpressure conditions. In order to derive maximum pressure of garnet growth, the rim composition of garnet and the phengite 1 composition of white mica were used (Figure 7, Tables 3 and 4), as our petrographic observations suggest that they grew in equilibrium during the same $P-T$ stage. Results predict peak $P-T$ conditions for garnet growth between $22-24$ kbar and $500-560{ }^{\circ} \mathrm{C}$ (Figure 14).

In sample SY1460, omphacite and phengite are also observed in textural equilibrium with the rim composition of the garnet (Figure 9). The phengite 2 composition has been used for thermobarometry and estimated $P-T$ conditions range from 19 to $21 \mathrm{kbar}$ and 500 to $560{ }^{\circ} \mathrm{C}$ for the growth of the garnet rim (Figure 14).

As a preliminary conclusion, results of empirical thermobarometry using compositional maps suggest maximum pressure and temperature for the garnet growth of the CBU of Syros at $22 \pm 2 \mathrm{kbar}$ and $530 \pm 30{ }^{\circ} \mathrm{C}$. Note that the assumption of chemical equilibrium between the different groups of garnet, phengite and omphacite are based on the petrographic observation and tested in the following using Gibbs free energy minimization. 


\section{3 | Garnet equilibrium modelling}

GRTMOD computations were performed on samples SY1401, SY1460, SY1407 and SY1418 using several compositions (WR and LB, Table 1) including or excluding MnO and using the JUN92.bs thermodynamic database (see the methods, section 3.3.2). The results are reported in $P-T$ diagrams (Figure 15) with error bars that represent the uncertainty in the optimal $P-T$ conditions resulting from the uncertainties in chemical analyses, taken as the spacing between the garnet isopleths (see Lanari et al., 2017). The residual values $\left(C_{o}\right.$ in the original publication, Lanari et al., 2017) represent the quality of the isopleths intersection, i.e. the quality between the modelled and observed garnet compositions. A value of $C_{o}<0.04$ ensures a good fit of the model and the fit is excellent where $C_{o}<0.01$. Isopleths of Si-content in phengite and Al-content in omphacite were calculated using the local bulk composition and are shown in the $P$ - $T$ diagrams of samples SY1401 and SY1460 (Figure 15).

In sample SY1401, predictions fall in a narrow $P$ - $T$ range using the $\mathrm{LB}$ and considering $\mathrm{MnO}$ or not (see the discussion below, section 6.1.2). A first event of garnet growth is constrained at 16-18 kbar and $450-500{ }^{\circ} \mathrm{C}$ (core) and a second event is suggested at $22-24$ kbar and $550-580{ }^{\circ} \mathrm{C}$ using the LB composition (rim, Figure 15). For this model, 20 vol\% of garnet is produced (core 2 vol\% and rim 18 vol\%; Figure 15).

In sample SY1460, garnet $P-T$ predictions can only be made using the LB composition and residual values are systematically high for all the models (above $>0.04$ ) suggesting either a smaller equilibrium volume, or kinetic phenomena (see discussion). In this model $\sim 9$ vol\% of garnet is produced (2 vol\% core and 7 vol\% rim).

In sample SY1407, the best defined models were obtained using the LB composition and suggest garnet growth for core, mantle and rim at lower pressure conditions of 10-12 kbar at 500-560 ${ }^{\circ} \mathrm{C}$. A less well defined but still acceptable model obtained using the WR and including $\mathrm{MnO}$ suggest garnet growth for core and mantle at 18-20 kbar and $470-500{ }^{\circ} \mathrm{C}$ (dark blue squares in Figure 15). In this last case, $2.5 \mathrm{vol} \%$ of garnet is produced (core $\sim 0.13 \mathrm{vol} \%$, mantle $0.57 \mathrm{vol} \%$ and rim $1.85 \mathrm{vol} \%$ ).

Finally, in sample SY1418, the only garnet $P-T$ predictions that are characterized by low residuals suggest homogeneous $P-T$ conditions for core and rim around $18 \pm 2 \mathrm{kbar}$ and $450 \pm 50{ }^{\circ} \mathrm{C}$ (Figure 15). In this case, 12 vol\% of garnet is produced (core $0.12 \mathrm{vol} \%$ and rim $11.8 \mathrm{vol} \%$ ). The models including $\mathrm{MnO}$ and with a garnet rim predicted at higher pressure show much higher garnet mode of 33 vol\% (core 12 vol\% and rim 21vol\%, Figure 15).

The main result of these models is that three main growth events of garnet are partially recorded in the four investigated samples (Figure 15). First, a prograde pulse of garnet growth is predicted from the core garnet composition of SY1401 and SY1418 at $17 \pm 2 \mathrm{kbar}$ and $450 \pm 50{ }^{\circ} \mathrm{C}$ (Figure 15). Then, the maximum pressure conditions recorded by garnet are estimated at 22-24 kbar and $550-580{ }^{\circ} \mathrm{C}$ from the rim garnet composition of SY1401 (circles in Figure 15). While these 
estimates are only retrieved in one sample, the residual values show a good fit of the model, and these conditions are consistent with maximum pressure conditions retrieved from the Si-content in phengite for SY1401 and from the Al-content in omphacite for SY1401 and SY1460 samples (Figures 7, 9 and 15). Finally, a last event of garnet growth is recorded in SY1407. This retrograde garnet growth event is well constrained between 9-12 kbar and $500-570{ }^{\circ} \mathrm{C}$, from both core, mantle and rim compositions of the garnet (Figure 15).

\section{$5.4 P-T$ isochemical phase diagrams}

Results obtained using garnet equilibrium modelling were compared with $P-T$ isochemical phase diagrams to test mutual consistency between predicted and observed mineral assemblages in sample SY1401 (Figure 16). Two phase diagrams using the LB and WR composition were calculated at $P-T$ conditions encompassing the first stage of core garnet crystallization determined by equilibrium modelling at 16-18 kbar and $450-500{ }^{\circ} \mathrm{C}$ (Figures 15 and 16). Two additional isochemical phase diagrams were then elaborated for $P-T$ conditions surrounding the second stage of rim garnet crystallization constrained at $22-24 \mathrm{kbar}$ and $550-580{ }^{\circ} \mathrm{C}$ (Figure 16). To calculate these diagrams, LB and WR compositions were modified to account for fractionation of garnet that crystallized during stage 1. For the first stage of garnet growth (core), the predicted assemblages are consistent with the minerals trapped as inclusions in garnet cores for both LB and WR compositions (Figure 16). Phengite, paragonite, omphacite and epidote are all predicted to be in equilibrium and observed in the garnet core (Figures 6 and 7), while rutile and quartz are not observed in the garnet porphyroblast that has been mapped but in other garnet cores of the same sample. Only chlorite is predicted in equilibrium but has not been clearly identified within the garnet core, consistent with a garnetforming reaction involving chlorite. Furthermore, on the compositional map of SY1401, albite is observed within the core of the garnet but not predicted in equilibrium for these $P$ - $T$ conditions. Albite was not completely destabilized when the garnet nucleated, suggesting significant $P-T$ overstepping with incomplete re-equilibration of the mineral matrix. If the matrix was only partially re-equilibrated at the time garnet nucleated, the inclusion phases in the garnet core do not reflect the equilibrium assemblage from which this garnet nucleated. In this scenario, the deviation from an equilibrium model cannot be approximated using an OS model (e.g. Castro \& Spear 2017; Spear, Thomas, \& Hallett, 2014). In this study, the $P-T$ conditions of garnet nucleation for three samples showing different matrix assemblages fall within a narrow $P-T$ window of $<30{ }^{\circ} \mathrm{C}$ and $<2 \mathrm{kbar}$. In the OS model, the garnet composition is fully controlled by the Gibbs free energy of the matrix assemblage (assuming equilibrium). Different matrix assemblages - for different bulk rock compositions - are likely to produce different degrees of overstepping (as reported by Castro \& Spear, 2017), which are not observed in this study.

For the second stage of garnet (rim), the two models produce different results as shown by the GRTMOD results (Figures 15 and 16). For the modified LB composition, the results show an excellent correlation between the predicted assemblage in equilibrium and petrographic observations with phengite, omphacite, epidote and quartz that are all observed as inclusions near the garnet rim and/or within the matrix (Figures 6 and 7). Rutile is not present in the mapped area but is commonly observed as an inclusion in the rim of other porphyroblasts of the same sample. Additionally, results obtained using the fractionated WR composition confirm that the calculated pressure prediction for the growth episode of the garnet rim is too high, as coesite is predicted above $25 \mathrm{kbar}$ and is not identified within the CBU (Figure 16). 


\section{6 | DISCUSSION AND CONCLUSIONS}

While Syros Island is a world-class reference for the preservation of HP-LT metamorphic rocks such as eclogite and blueschist, the $P-T$ path of the CBU in this island is not completely understood (Figure 1 ), hindering our global understanding of exhumation processes and deep subduction dynamics. This study complements results obtained in previous thermobarometric studies conducted in the CBU (Ashley, Caddick, Steele-MacInnis, Bodnar, \& Dragovic 2014; Dragovic, Baxter, \& Caddick, 2015; Dragovic, Samanta, Baxter, \& Selverstone, 2012; Groppo, Forster, Lister, \& Compagnoni, 2009; Huet, Labrousse, Monié, Malvoisin, \& Jolivet, 2015; Parra, Vidal, \& Jolivet, 2002; Schumacher et al., 2008; Trotet et al., 2001b). Our new $P$ - $T$ estimates for the CBU on Syros highlight a two-step exhumation history in the subduction channel, resembling ones previously retrieved on Tinos and Andros islands (Huet et al., 2015; Parra et al., 2002) but which have not been described on Syros thus far.

\section{1 | $P$-T path and comparison of the methods}

\subsection{1 | P-T path of the CBU on Syros}

In this study, different independent thermobarometric methods such as RSCM peak-temperatures, empirical thermobarometry and thermodynamic modelling have been used to reconstruct the $P-T$ path of the CBU on Syros (Figure 17). The most important result of our study is the good agreement between the different methods used in different samples, which allows the $P$ - $T$ evolution of the CBU to be accurately determined (Figure 17). All methods used in this study provide results in line with the petrological observations. Peak metamorphic temperatures measured with the RSCM method are in good agreement with maximum temperatures estimated for both empirical and garnet thermobarometry at $530 \pm 30{ }^{\circ} \mathrm{C}$ (Figure 17). Additionally, minimum peak metamorphic $P-T$ conditions obtained with empirical thermobarometry $\left(22-24\right.$ kbar for $500-560{ }^{\circ} \mathrm{C}$ and $19-21 \mathrm{kbar}$ for $500-560{ }^{\circ} \mathrm{C}$ ) fall in the same range of maximum $P$-T conditions calculated with GRTMOD (22-24 kbar and 550-580 ${ }^{\circ} \mathrm{C}$, Figure 17). The retrograde path is constrained through an event of garnet growth occurring at $10-12 \mathrm{kbar}$ and $500-570{ }^{\circ} \mathrm{C}$ that suggests a period of relatively isobaric heating. This late event is only recorded in retrogressed samples from the basal and mid-part of the CBU on Syros. RSCM-T estimates provide also an upper limit to the maximum amount of heating during this period. The P-T trajectory is consequently well constrained, at least for the prograde to peak part and the retrograde event (Figure 17).

\subsection{2 | Bulk composition and kinetic sensitivity in equilibrium models}

As the isochemical equilibrium phase diagrams and isopleth positions critically depend on the bulk composition used for modelling, WR compositions and LB composition extracted from compositional maps were measured. Both compositions were systematically tested, considering or not $\mathrm{MnO}$ (Figure 15). While $\mathrm{MnO}$ has a direct impact on the modal abundance of garnet produced, the models computed either with WR or LB and assuming a MnO-free system generally have lower residue values (or at least similar, Figure 15). A significant amount of $\mathrm{MnO}$ is measured in all garnet cores and in the mantle composition of the SY1407 garnet $\left(\mathrm{XSps}_{0.06-0.11}\right.$; Table 3). Our results show relative mutual consistency between WR and LB compositions without MnO (light blue colour in Figure 15) that yield close predictions in samples SY1401, SY1407 and SY1418. When considering MnO, 
results show more variations between the predicted garnet $P-T$ equilibrium using WR or LB compositions as shown in samples SY1407 and SY1418, demonstrating that considering MnO in the models is critical in this study. Note that a significant higher fraction of garnet is predicted for models including $\mathrm{MnO}$ in sample SY1418 (from 12 to 33 vol\%). To compare the observed and predicted modes of garnet, it is necessary to include $\mathrm{MnO}$, as garnet is the main carrier of $\mathrm{Mn}$ in these rocks (see also Tinkham, Zuluaga, \& Stowell, 2001).

Moreover, this work highlights the powerful use of LB composition calculated from the composition of local assemblages identified on compositional maps as an approximation of reactive bulk compositions for thermodynamic modelling. Because of the local heterogeneities of metamorphic rocks and the compositional zoning of the rock-forming minerals, the measured wholerock composition is not always adapted for modelling (e.g. Lanari et al., 2013; Loury et al., 2015; Warren \& Waters, 2006). In this study, several examples suggest that the models based on LB provide better results (lower residuals for similar $P$ - $T$ conditions). This result is in line with small equilibration volumes, which would, for example, be smaller than hand specimen sample used to estimate the bulk rock composition. The quantitative mapping strategy employed in this study helps to ensure that the composition of each textural-domain is accurately determined (Lanari \& Engi, 2017; Lanari et al. 2018). This would not be the case by using only qualitative maps and EPMA spot analyses.

Sample SY-14-60 is an interesting case study as the compositional maps show evidence of transport-controlled growth with the oscillatory zoning of $\mathrm{MnO}$ (Figure 9). In this case, high residuals are obtained in GRTMOD (Figure 15), suggesting that the part of the rock considered in the models never reached whole-scale chemical equilibrium during the entire $P$ - $T$ cycle. Other potential cause for $\mathrm{MnO}$ oscillatory zoning in the garnet, such as externally-derived fluid, is not likely due to the very low solubility of $\mathrm{Mn}$ in the fluid at HP conditions. All other samples show compositional zoning more typical of growth zoning suggesting equilibrium-controlled growth (Figures 7, 11 and 13). In this case, the successive compositions of garnet can be related to differences in $P$ - $T$ conditions and the models have lower residuals (Figure 15).

\section{2 $\mid P$-T evolution of the CBU}

In light of our results, the shape of the $P-T$ path of the CBU on Syros is constrained by prograde, peak and retrograde garnet growth stages, maximum RSCM temperature and peak pressure crystallization of the garnet-omphacite-phengite assemblage (Figure 17).

Preservation of prograde mineral parageneses constraining the burial $P-T$ conditions of HPLT metamorphic rocks is rare and often preserved only in garnet cores. In our study, late burial $P-T$ conditions of the $\mathrm{CBU}$ in the subduction zone is constrained by a garnet growth stage that was recorded in three samples at $17 \pm 2 \mathrm{kbar}$ and $450 \pm 50{ }^{\circ} \mathrm{C}$ (Figures 15 and 17). On Sifnos, the other Cycladic island where HP-LT eclogites and blueschists are well preserved, prograde garnet growth event has been also retrieved at $\sim 20 \mathrm{kbar}$ and $450-500{ }^{\circ} \mathrm{C}$ (Dragovic et al., 2012; Groppo et al., 2009). The timing of this early growth of garnet is well constrained at $53.4 \pm 2.6 \mathrm{Ma}$ (Dragovic et al., 2015). 
We have obtained consistent peak metamorphic $P-T$ conditions from the three subunits of the $\mathrm{CBU}$ using independent thermobarometric methods at $22 \pm 2 \mathrm{kbar}$ and $530 \pm 30^{\circ} \mathrm{C}$ (Figure 17). These conditions differ significantly from the results of Schumacher et al. (2008) who proposed lower peak metamorphic conditions at $15-16 \mathrm{kbar}$ and $500{ }^{\circ} \mathrm{C}$ (Figure 1). Our results are thus in line with peak $P$ $T$ conditions proposed on Syros by Trotet et al. (2001b) and with other recent studies conducted on Sifnos (Ashley et al., 2014; Dragovic et al., 2012, 2015; Groppo et al., 2009).

The shape of the retrograde $P-T$ path is characterized by a two-step exhumation history delimited by a phase of isobaric heating for the two lowermost subunits, Chroussa and Posidonia (Figure 17). The first step of exhumation was achieved under HP-LT conditions for all units, permitting the preservation of eclogite- and blueschist-facies parageneses. Such shape of the $P-T$ path for early exhumation following peak $P-T$ conditions is also retrieved on Sifnos Island (Groppo et al., 2009). Moreover, this retrograde evolution of the CBU on Syros is close to that proposed by Lister and Forster (2016), except for their unconstrained retrograde $P$ - $T$ loops (Figures 1 and 17). After this first step of exhumation, a last garnet growth event was recorded at lower $P-T$ conditions (Figures 15 and 17). In our interpretation, this retrograde garnet growth event is related to a phase of relatively isobaric heating at 10-12 kbar and 500-570 ${ }^{\circ} \mathrm{C}$ (Figure 17). Because samples of the Kampos Subunit are not very retrogressed, we suggest that rocks of this subunit have not been affected by this heating and have continued to be exhumed under HP-LT conditions.

Recently proposed (but not constrained) for the CBU on Syros by Lister and Forster (2016), this heating phase was previously retrieved on Tinos and Andros islands (Huet et al., 2015; Parra et al., 2002). On Tinos, this phase was estimated at 9-10 kbar and between 400 and $550{ }^{\circ} \mathrm{C}$, while on Andros, it was estimated at lower conditions of 7 kbar and 300-420 ${ }^{\circ} \mathrm{C}$ (Huet et al., 2015; Parra et al., 2002). Finally, our results do not permit determining the second phase of exhumation that followed the heating period. However, consistent $P-T$ conditions of this late phase of ductile exhumation have been estimated on Syros, Sifnos, Tinos and Andros, and were utilized to draw a complete $P-T$ path of the CBU (Huet et al., 2016; Parra et al., 2002; Trotet et al., 2001b; Figure 17).

To conclude, the $P-T$ path proposed in this study for the CBU on Syros differs significantly from the preceding ones (Figures 1 and 17). Our new estimates partly reinforce the conclusion of Trotet et al. (2001b), who suggested that the $P-T$ evolution was not the same throughout the nappe pile and that the best-preserved parts at the top had been exhumed along a colder path than the lower units. Here, however, we show in addition that the evolutions of the three subunits were similar during the first part of exhumation, from $22 \mathrm{kbar}$ to $10 \mathrm{kbar}$ and that they diverged from that point, with the lower units being heated at constant pressure before their final exhumation, a precision not attained with the methods used by Trotet et al. (2001b). In our interpretation, the increasing gradient of retrogression in the greenschist-facies conditions observed toward the base of the CBU is directly linked to these different $P-T$ evolutions. The geodynamic implications of these results are discussed in the following section. 


\subsection{Implications for exhumation processes and deep dynamics in the Hellenic subduction zone}

The tectonometamorphic history of the CBU has been the focus of many works in the last decades. In this section, we synthetize these studies in an attempt to deepen understanding of exhumation processes and deep dynamics in the subduction zone.

The conditions of peak metamorphic $P-T$ conditions in the CBU on Syros have been debated in the literature (Figure 1, e.g. Schumacher et al., 2008; Trotet et al., 2001b). In light of our results and considering recent studies conducted on Sifnos, it seems now clear that the CBU was buried deeply in the subduction zone at a minimum of $60-65 \mathrm{~km}$, assuming lithostatic pressure (Ashley et al., 2014; Dragovic et al., 2012, 2015; Groppo et al., 2009; Trotet et al., 2001b). Burial of the CBU is characterized by top-to-the SW sense of shear (Philippon et al., 2011; Roche, Laurent, Cardello, Jolivet, \& Scaillet, 2016). For example, Philippon et al. (2011) identified on Syros prograde top-to-the SW sense of shear affecting pseudomorphs of lawsonite, while kilometric SW verging folds have been interpreted as prograde drag folds on Sifnos (Roche et al., 2016; see also Aravadinou, Xypolias, Chatzaras, Iliopoulos, \& Gerogiannis, 2016, for the early top-to-the south component of the burial path).

Moreover, the $P-T$ path proposed in this study for the CBU on Syros shows interesting similarities with those previously proposed for Tinos and Andros islands (Huet et al., 2015; Parra et al., 2002). The main characteristic of these paths is the two-step exhumation history delimited by an isobaric phase of heating (Figure 17). The first part of the retrograde path constrains the $P-T$ conditions of a syn-orogenic phase of exhumation from eclogite- to blueschist-facies conditions. On Syros, the timing of this first exhumation step, accommodated within the subduction channel while the overall regime was still under compression, is constrained between 50 and $35 \mathrm{Ma}$ by ${ }^{40} \mathrm{Ar} /{ }^{39} \mathrm{Ar}$ and $\mathrm{Rb} / \mathrm{Sr}$ ages (Cliff et al., 2017; Laurent et al., 2017; Lister \& Forster, 2016). Syn-orogenic exhumation kinematic indicators are well exposed on Syros, Sifnos and Tinos, showing a clear top-to-the E/NE sense of shear observed in preserved HP rocks (Gautier \& Brun, 1994; Jolivet \& Patriat, 1999; Laurent et al., 2016; Philippon et al., 2011; Roche et al., 2016; Trotet et al., 2001a). The main structure accommodating this top-to-the NE deformation is the Vari Detachment described on Syros and Tinos and located at the roof of the CBU. Ring et al. (2010) interpreted this deformation as a synconvergent extensional shearing at the top of an extruding wedge, contemporaneous with thrusting at the base of the wedge. This is consistent with a syn-orogenic exhumation of the CBU between a basal thrust, observed on Ios, and a detachment at the top, the Vari Detachment (Huet et al., 2009; Jolivet \& Brun, 2010; Jolivet et al., 2003).

A pause in the exhumation accompanied by isobaric heating at the base of the crust has also been previously shown on Tinos and Andros. This study recognizes the record of this re-heating period in Syros, except for the top of the CBU where HP-LT parageneses are the best preserved (i.e. in Kampos Subunit; Figure 17). This phase coincides with a change in subduction dynamics, and the settling of a faster slab retreat, coeval with the migration of the subduction front southward within the more external zones (Phyllite-Quartzite Nappe in Crete and on the Peloponnese; Jolivet \& Brun, 2010; Jolivet et al., 2003). Slab retreat then induced large-scale back-arc extension leading to thermal re-equilibration of the lithosphere from a cold syn-orogenic regime in the subduction zone to a 
warmer post-orogenic regime in the back-arc domain (Jolivet \& Brun, 2010; Parra et al., 2002). The timing of this isobaric heating has been determined on Tinos and Andros between 37 and $30 \mathrm{Ma}$ (Bröcker, Bieling, Hacker, \& Gans, 2004; Bröcker, Kreuzer, Matthews, \& Okrusch, 1993; Huet et al., 2015) and needs further temporal constraints on Syros. An interesting feature is that the degree of heating was practically identical on Tinos and Andros $\left(\sim 120-150{ }^{\circ} \mathrm{C}\right)$ but seems to be lower on Syros $\left(\sim 60-70{ }^{\circ} \mathrm{C}\right)$, which probably allows better preservation of HP-LT metamorphic rocks on Syros.

Finally, the last part of the retrograde path of the CBU on Syros, Tinos and Andros constrains the $P-T$ conditions of the post-orogenic phase of exhumation from blueschist- to greenschist-facies conditions (Figure 17; Huet et al., 2015; Parra et al., 2002). The timing of this last ductile exhumation phase is constrained between 30 and $20 \mathrm{Ma}$ by ${ }^{40} \mathrm{Ar} /{ }^{39} \mathrm{Ar}$ and $\mathrm{Rb} / \mathrm{Sr}$ ages (Bröcker, Baldwin, \& Arkudas, 2013; Bröcker \& Franz, 1998, 2005; Bröcker et al., 1993; Forster \& Lister, 2005; Laurent et al., 2017). This post-orogenic phase of exhumation is mainly accommodated by opposing-sense sets of detachment such as the North Cycladic Detachment System (NCDS, Jolivet et al., 2010), associated with syn-greenschist top-to-the NE sense of shear, or the West Cycladic Detachment System (WCDS, Grasemann et al., 2012), a syn-greenschist top-to-the SW system of detachments outcropping on Serifos, Kythnos and Kea islands. Then, final exhumation stages of the CBU toward the surface were accommodated by post-metamorphic brittle deformation through low-angle and steeply dipping normal faults (e.g. Jolivet \& Patriat, 1999; Jolivet et al., 2004; Keiter et al., 2011; Mehl, Jolivet, \& Lacombe, 2005; Philippon et al., 2011; Ring, Thomson, \& Bröcker, 2003; Ring et al., 2010).

The multi-stage exhumation process of the CBU within the Hellenic subduction zone is strongly governed by slab rollback. Expanding to the general aspects of subduction zones, we suggest that such metamorphic evolution of HP-LT units, with two exhumation stages delimited by a phase of isobaric heating, should be regarded as a characteristic feature of exhumation driven by slab rollback. To better understand the transition from crustal thickening (syn-orogenic) to back-arc extension (postorogenic) and the dynamics of the subduction channel, it is of paramount importance to know (1) when and at which depth heating has started, (2) whether or not the HP-LT metamorphic units has first been exhumed along a cooling path similar to that retrieved on Syros, and (3) what is the mechanical significance of the depth at which this isobaric heating took place.

\section{ACKNOWLEDGEMENTS}

This work has received funding from the European Research Council (ERC) under the seventh Framework Program of the European Union (ERC Advanced Grant, grant agreement No 290864, RHEOLITH) and from the Institut Universitaire de France. It is a contribution of the Labex VOLTAIRE. The authors are grateful to S. Janiec and J.G. Badin (ISTO) for the preparation of thin sections and V. Magnin and V. Batanova (ISTerre) for the acquisition of X-Ray compositional maps. Finally, we thank B. Dragovic for insightful and helpful reviews and D. Whitney for careful and constructive editorial handling. 


\section{REFERENCES}

Airaghi L., Lanari P., de Sigoyer J., \& Guillot S. (2017). Microstructural vs compositional preservation and pseudomorphic replacement of muscovite in deformed metapelites from the Longmen Shan (Sichuan, China). Lithos, 282-283, 262-280

Aoya, M., Kouketsu, Y., Endo, S., Shimizu, H., Mizukami, T., Nakamura, D., \& Wallis, S. (2010). Extending the applicability of the Raman carbonaceous - material geothermometer using data from contact metamorphic rocks. Journal of Metamorphic Geology, 28(9), 895-914.

Aravadinou, E., Xypolias, P., Chatzaras, V., Iliopoulos, I., \& Gerogiannis, N. (2016). Ductile nappe stacking and refolding in the Cycladic Blueschist Unit: insights from Sifnos Island (south Aegean Sea). International Journal of Earth Sciences, 105, 2075-2096.

Ashley, K.T., Caddick, M.J., Steele-MacInnis, M.J., Bodnar, R.J., \& Dragovic, B. (2014). Geothermobarometric history of subduction recorded by quartz inclusions in garnet. Geochemistry, Geophysics, Geosystems, 15, 350-360.

Augier, R., Jolivet, L., Gadenne, L., Lahfid, A., \& Driussi, O. (2015). Exhumation kinematics of the Cycladic Blueschists unit and back - arc extension, insight from the Southern Cyclades (Sikinos and Folegandros Islands, Greece). Tectonics, 34(1), 152-185.

Berman, R.G. (1988). Internally-consistent thermodynamic data for minerals in the system $\mathrm{Na}_{2} \mathrm{O}-$ $\mathrm{K}_{2} \mathrm{O}-\mathrm{CaO}-\mathrm{MgO}-\mathrm{FeO}-\mathrm{Fe}_{2} \mathrm{O}_{3}-\mathrm{Al}_{2} \mathrm{O}_{3}-\mathrm{SiO}_{2}-\mathrm{TiO}_{2}-\mathrm{H}_{2} \mathrm{O}-\mathrm{CO}_{2}$. Journal of Petrology, 29, 445-522.

Berman, R.G. (1991). Thermobarometry using multi-equilibrium calculations: a new technique, with petrological applications. Canadian Mineralogist, 29, 833-855.

Beyssac, O., Goffé, B., Chopin, C., \& Rouzaud, J.N. (2002a). Raman spectra of carbonaceous material in metasediments: a new geothermometer. Journal of metamorphic Geology, 20, 859-871.

Beyssac, O., Rouzaud, J.-N., Goffe, B., Brunet, F., \& Chopin, C. (2002b). Graphitization in a highpressure, low temperature metamorphic gradient: A Raman micro-spectroscopy and HRTEM study. Contributions to Mineralogy and Petrology, 143, 19-31.

Bonneau, M. (1984). Correlation of the Hellenide nappes in the south-east Aegean and their tectonic reconstruction. Geological Society, London, Special Publications, 17, 517-527.

Bonneau, M., \& Kienast, J.R. (1982). Subduction, collision et schistes bleus; l'exemple de l'Egee (Grece). Bulletin de la société Géologique de France, 785-791.

Bröcker, M., Baldwin, S., \& Arkudas, R. (2013). The geological significance of 40Ar/39Ar and RbSr white mica ages from Syros and Sifnos, Greece: a record of continuous (re) crystallization during exhumation?. Journal of Metamorphic Geology, 31(6), 629-646.

Bröcker, M., Bieling, D., Hacker, B., \& Gans, P. (2004). High-Si phengite records the time of greenschist facies overprinting: implications for models suggesting mega-detachments in the Aegean Sea. Journal of Metamorphic Geology, 22, 427-442.

Bröcker, M. \& Franz, L. (1998). Rb-Sr isotope studies on Tinos Island (Cyclades, Greece): additional time constraints for metamorphism, extent of infiltration-controlled overprinting and 
deformational activity. Geological Magazine, 135, 369-382.

Bröcker, M., \& Franz, L. (2005). The base of the Cycladic blueschist unit on Tinos Island (Greece) re-visited: field relationships, phengite chemistry and $\mathrm{Rb}-\mathrm{Sr}$ geochronology. Journal of Mineralogy and Geochemistry, 181, 81-93.

Bröcker, M., Kreuzer, H., Matthews, A., \& Okrusch, M. (1993). 40Ar/39Ar and oxygen isotope studies of polymetamorphism from Tinos Island, Cycladic blueschist belt, Greece. Journal of Metamorphic Geology, 11, 223-240.

Brovarone, A.V., Beyssac, O., Malavieille, J., Molli, G., Beltrando, M., \& Compagnoni, R. (2013). Stacking and metamorphism of continuous segments of subducted lithosphere in a highpressure wedge: the example of Alpine Corsica (France). Earth-Science Reviews, 116, 35-56.

Brun, J.-P., \& Faccenna, C. (2008). Exhumation of high-pressure rocks driven by slab rollback. Earth and Planetary Science Letters, 272, 1-7.

Caddick, M.J., Konopásek, J., \& Thompson, A.B. (2010). Preservation of garnet growth zoning and the duration of prograde metamorphism. Journal of Petrology, 51, 2327-2347.

Castro, A. E., \& Spear, F. S. (2017). Reaction overstepping and re-evaluation of peak P-T conditions of the blueschist unit on Sifnos, Greece: implications for the Cyclades subduction zone. International Geology Review, 59(5-6), 548-562.

Cliff, R. A., Bond, C. E., Butler, R. W. H., \& Dixon, J. E. (2017). Geochronological challenges posed by continuously developing tectonometamorphic systems: insights from $\mathrm{Rb}-\mathrm{Sr}$ mica ages from the Cycladic Blueschist Belt, Syros (Greece). Journal of Metamorphic Geology, 35(2), 197-211.

De Andrade, V., Vidal, O., Lewin, E., O'brien, P., \& Agard, P. (2006). Quantification of electron microprobe compositional maps of rock thin sections: an optimized method and examples. Journal of Metamorphic Geology, 24(7), 655-668.

De Capitani, \& C., Brown, T.H. (1987). The computation of chemical equilibrium in complex systems containing non-ideal solutions. Geochimica et Cosmochimica Acta, 51, 2639-2652.

De Capitani, C., \& Petrakakis, K. (2010). The computation of equilibrium assemblage diagrams with Theriak/Domino software. American Mineralogist, 95, 1006-1016.

Dragovic, B., Baxter, E.F., \& Caddick, M.J. (2015). Pulsed dehydration and garnet growth during subduction revealed by zoned garnet geochronology and thermodynamic modeling, Sifnos, Greece. Earth and Planetary Science Letters, 413, 111-122.

Dragovic, B., Samanta, L.M., Baxter, E.F., \& Selverstone, J. (2012). Using garnet to constrain the duration and rate of water-releasing metamorphic reactions during subduction: An example from Sifnos, Greece. Chemical Geology, 314, 9-22.

Evans, B.W. (1990). Phase relations of epidote-blueschists. Lithos, 25, 3-23.

Fiannacca, P., Pò, D. L., Ortolano, G., Cirrincione, R., \& Pezzino, A. (2012). Thermodynamic modeling assisted by multivariate statistical image analysis as a tool for unraveling metamorphic PTd evolution: an example from ilmenite-garnet-bearing metapelite of the 
Peloritani Mountains, Southern Italy. Mineralogy and Petrology, 106(3-4), 151-171.

Forster, M.A., \& Lister, G.S. (2005). Several distinct tectono-metamorphic slices in the Cycladic eclogite-blueschist belt, Greece. Contributions to Mineralogy and Petrology, 150, 523-545.

Gabalda, S., Beyssac, O., Jolivet, L., Agard, P., \& Chopin, C. (2009). Thermal structure of a fossil subduction wedge in the Western Alps. Terra Nova, 21, 28-34.

Gautier, P., Brun, J.-P., \& Jolivet, L. (1993). Structure and kinematics of upper Cenozoic extensional detachment on Naxos and Paros (Cyclades Islands, Greece). Tectonics, 12, 1180-1194.

Gautier, P., \& Brun, J.P. (1994). Ductile crust exhumation and extensional detachments in the central Aegean (Cyclades and Evvia Islands). Geodinamica Acta, 7, 57-85.

Giuntoli, F., Lanari, P., \& Engi, M. (2018). Deeply subducted continental fragments: Fracturing, dissolution-precipitation and diffusion processes recorded by garnet textures of the central Sesia Zone (Western Italian Alps). Solid Earth DOI: 10.5194/se-2017-87

Grasemann, B., Schneider, D. A., Stöckli, D. F., \& Iglseder, C. (2012). Miocene bivergent crustal extension in the Aegean: Evidence from the western Cyclades (Greece). Lithosphere, 4(1), 23-39.

Groppo, C., Forster, M., Lister, G., \& Compagnoni, R. (2009). Glaucophane schists and associated rocks from Sifnos (Cyclades, Greece): New constraints on the P-T evolution from oxidized systems. Lithos, 109, 254-273.

Holland, T.J.B., \& Powell, R. (1998). An internally consistent thermodynamic data set for phases of petrological interest. Journal of metamorphic Geology, 16, 309-343.

Huet, B., Labrousse, L., \& Jolivet, L. (2009). Thrust or detachment? Exhumation processes in the Aegean: insight from a field study on Ios (Cyclades, Greece). Tectonics, 28(3). Huet, B., Labrousse, L., Monié, P., Malvoisin, B., \& Jolivet, L. (2015). Coupled phengite $40 \mathrm{Ar}-39 \mathrm{Ar}$ geochronology and thermobarometry: P-T-t evolution of Andros Island (Cyclades, Greece). Geological Magazine, 152, 711-727.

Jolivet, L., \& Brun, J.-P. (2010). Cenozoic geodynamic evolution of the Aegean. International Journal of Earth Sciences, 99, 109-138.

Jolivet, L., Daniel, J.M., Truffert, C., \& Goffé, B. (1994). Exhumation of deep crustal metamorphic rocks and crustal extension in arc and back-arc regions. Lithos, 33, 3-30.

Jolivet, L., Faccenna, C., Goffé, B., Burov, E., \& Agard, P. (2003). Subduction tectonics and exhumation of high-pressure metamorphic rocks in the Mediterranean orogens. American Journal of Science, 303, 353-409.

Jolivet, L., Faccenna, C., Huet, B., Labrousse, L., Le Pourhiet, L., Lacombe, O., ... \& Philippon, M. (2013). Aegean tectonics: Strain localisation, slab tearing and trench retreat. Tectonophysics, $597,1-33$.

Jolivet, L., Lecomte, E., Huet, B., Denèle, Y., Lacombe, O., Labrousse, L., ... \& Mehl, C. (2010). The north cycladic detachment system. Earth and Planetary Science Letters, 289(1-2), 87-104. 
Jolivet, L., \& Patriat, M. (1999). Ductile extension and the formation of the Aegean Sea. Geological Society, London, Special Publications, 156, 427-456.

Jolivet, L., Rimmelé, G., Oberhänsli, R., Goffé, B., \& Candan, O. (2004). Correlation of syn-orogenic tectonic and metamorphic events in the Cyclades, the Lycian nappes and the Menderes massif. Geodynamic implications. Bulletin de la Société Géologique de France, 175, $217-$ 238.

Keiter, M., Ballhaus, C., \& Tomaschek, F. (2011). A new geological map of the Island of Syros (Aegean Sea, Greece): Implications for lithostratigraphy and structural history of the Cycladic Blueschist Unit. Geological Society of America Special Papers, 481, 1-43.

Keiter, M., Piepjohn, K., Ballhaus, C., Lagos, M., \& Bode, M. (2004). Structural development of high-pressure metamorphic rocks on Syros island (Cyclades, Greece). Journal of Structural Geology, 26, 1433-1445.

Kohn, M. J. (2014). Geochemical Zoning in Metamorphic Minerals A2. Treatise on Geochemistry (Second Edition): Oxford, Elsevier, 249-280.

Kohn, M.J., \& Spear, F. (2000). Retrograde net transfer reaction insurance for pressure-temperature estimates. Geology, 28, 1127-1130.

Konrad-Schmolke, M., O'Brien, P.J., de Capitani, C., \& Carswell, D.A. (2008). Garnet growth at high-and ultra-high pressure conditions and the effect of element fractionation on mineral modes and composition. Lithos, 103, 309-332.

Lagos, M., Scherer, E.E., Tomaschek, F., Münker, C., Keiter, M., Berndt, J., \& Ballhaus, C. (2007). High precision Lu-Hf geochronology of Eocene eclogite-facies rocks from Syros, Cyclades, Greece. Chemical Geology, 243, 16-35.

Lanari, P., Guillot, S., Schwartz, S., Vidal, O., Tricart, P., Riel, N., \& Beyssac, O. (2012). Diachronous evolution of the alpine continental subduction wedge: evidence from $\mathrm{P}-\mathrm{T}$ estimates in the Briançonnais Zone houillère (France-Western Alps). Journal of Geodynamics, 56, 39-54.

Lanari, P., Riel, N., Guillot, S., Vidal, O., Schwartz, S., Pêcher, A., \& Hattori, K.H. (2013). Deciphering high-pressure metamorphism in collisional context using microprobe mapping methods: Application to the Stak eclogitic massif (northwest Himalaya). Geology, 41, 111114.

Lanari, P., Vidal, O., De Andrade, V., Dubacq, B., Lewin, E., Grosch, E.G., \& Schwartz, S. (2014). XMapTools: A MATLAB \copyright-based program for electron microprobe X-ray image processing and geothermobarometry. Computers \& Geosciences, 62, 227-240.

Lanari, P., \& Engi, M. (2017). Local bulk composition effects on mineral assemblages. Reviews in Mineralogy and Geochemistry, 83.

Lanari, P., Giuntoli, F., Loury, C., Burn, M., \& Engi, M. (2017). An inverse modeling approach to obtain P-T conditions of metamorphic stages involving garnet growth and resorption. European Journal of Mineralogy, 29(2), 181-199.

Lanari, P., Vho, A., Bovay, T., Airaghi, L., \& Centrella, S. (2018). Quantitative compositional mapping of 
mineral phases by electron probe micro-analyser. Geological Society of London Special Publication, DOI: $10.1144 / \mathrm{SP} 478.4$

Laurent, V., Jolivet, L., Roche, V., Augier, R., Scaillet, S., \& Cardello, G. L. (2016). Strain localization in a fossilized subduction channel: Insights from the Cycladic Blueschist Unit (Syros, Greece). Tectonophysics, 672, 150-169.

Laurent, V., Huet, B., Labrousse, L., Jolivet, L., Monie, P., \& Augier, R. (2017). Extraneous argon in high-pressure metamorphic rocks: Distribution, origin and transport in the Cycladic Blueschist Unit (Greece). Lithos, 272, 315-335.

Le Pichon, X., \& Angelier, J. (1981). The Aegean Sea. Royal Society of London Philosophical Transactions Series A, 300, 357-372.

Lister, G. S., \& Forster, M. A. (2016). White mica ${ }^{40} \mathrm{Ar} /{ }^{39} \mathrm{Ar}$ age spectra and the timing of multiple episodes of high - P metamorphic mineral growth in the Cycladic eclogite-blueschist belt, Syros, Aegean Sea, Greece. Journal of Metamorphic Geology, 34(5), 401-421.

Lister, G.S., Banga, G., \& Feenstra, A. (1984). Metamorphic core complexes of Cordilleran type in the Cyclades, Aegean Sea, Greece. Geology, 12, 221-225.

Loury, C., Rolland, Y., Cenki-Tok, B., Lanari, P., \& Guillot, S. (2015). Late Paleozoic evolution of the South Tien Shan: Insights from P-T estimates and allanite geochronology on retrogressed eclogites (Chatkal range, Kyrgyzstan). Journal of Geodynamics, 96, 62-80.

Marmo B.A., Clarke G.L., \& Powell R. (2002). Fractionation of bulk rock composition due to porphyroblast growth: effects on eclogite facies mineral equilibria, Pam Peninsula, New Caledonia. Journal of Metamorphic Geology, 20(1), 151-165. doi:10.1046/j.0263-

4929.2001.00346.x

Mehl, C., Jolivet, L., \& Lacombe, O. (2005). From ductile to brittle: evolution and localization of deformation below a crustal detachment (Tinos, Cyclades, Greece). Tectonics, 24(4).

Moynihan, D.P., \& Pattison, D.R.M. (2013). An automated method for the calculation of P-T paths from garnet zoning, with application to metapelitic schist from the Kootenay Arc, British Columbia, Canada. Journal of Metamorphic Geology, 31, 525-548.

Parra, T., Vidal, O., \& Jolivet, L. (2002). Relation between the intensity of deformation and retrogression in blueschist metapelites of Tinos Island (Greece) evidenced by chlorite-mica local equilibria. Lithos, 63, 41-66.

Peacock, S. M. (1993). The importance of blueschist $\rightarrow$ eclogite dehydration reactions in subducting oceanic crust. Geological Society of America Bulletin, 105(5), 684-694.

Philippon, M., Brun, J. P., \& Gueydan, F. (2011). Tectonics of the Syros blueschists (Cyclades, Greece): From subduction to Aegean extension. Tectonics, 30(4).

Ravna, E. K. (2000). The garnet-clinopyroxene $\mathrm{Fe}^{2+}-\mathrm{Mg}$ geothermometer: an updated calibration. Journal of Metamorphic Geology, 18(2), 211-219.

Ring, U., Glodny, J., Will, T., \& Thomson, S. (2010). The Hellenic subduction system: high-pressure metamorphism, exhumation, normal faulting, and large-scale extension. Annual Review of 
Earth and Planetary Sciences, 38, 45-76.

Ring, U., Thomson, S., \& Bröcker, M. (2003). Fast extension but little exhumation: the Vari detachment in the Cyclades, Greece. Geological Magazine, 140, 245-252.

Ring, U., Will, T., Glodny, J., Kumerics, C., Gessner, K., Thomson, S., ... \& Drüppel, K. (2007). Early exhumation of high - pressure rocks in extrusion wedges: Cycladic blueschist unit in the eastern Aegean, Greece, and Turkey. Tectonics, 26(2).

Roche, V., Laurent, V., Cardello, G.L., Jolivet, L., \& Scaillet, S. (2016). Anatomy of the Cycladic Blueschist Unit on Sifnos Island (Cyclades, Greece). Journal of Geodynamics, 97, 62-87.

Rubatto, D., Regis, D., Hermann, J., Boston, K., Engi, M., Beltrando, M., \& McAlpine, S. R. (2011). Yo-yo subduction recorded by accessory minerals in the Italian Western Alps. Nature Geoscience, 4(5), 338.

Schumacher, J.C., Brady, J.B., Cheney, J.T., \& Tonnsen, R.R. (2008). Glaucophane-bearing marbles on Syros, Greece. Journal of Petrology, 49, 1667-1686.

Soukis, K., \& Stockli, D.F. (2013). Structural and thermochronometric evidence for multi-stage exhumation of southern Syros, Cycladic islands, Greece. Tectonophysics, 595, 148-164.

Spear, F.S. (1988). Metamorphic fractional crystallization and internal metasomatism by diffusional homogenization of zoned garnets. Contributions to Mineralogy and Petrology, 99, 507-517.

Spear, F. S., Thomas, J. B., \& Hallett, B. W. (2014). Overstepping the garnet isograd: a comparison of QuiG barometry and thermodynamic modeling. Contributions to Mineralogy and Petrology, 168(3), 1059.

Tedeschi, M., Lanari, P., Rubatto, D., Pedrosa-Soares, A., Hermann, J., Dussin, I., ... \& Baumgartner, L. (2017). Reconstruction of multiple PTt stages from retrogressed mafic rocks: Subduction versus collision in the Southern Brasília orogen (SE Brazil). Lithos, 294, 283-303.

Tinkham, D. K., Zuluaga, C. A., \& Stowell, H. H. (2001). Metapelite phase equilibria modeling in MnNCKFMASH: the effect of variable $\mathrm{Al} 2 \mathrm{O} 3$ and $\mathrm{MgO} /(\mathrm{MgO}+\mathrm{FeO})$ on mineral stability. Geological Materials Research, 3(1), 1-42.

Tomaschek, F., Kennedy, A.K., Villa, I.M., Lagos, M., \& Ballhaus, C. (2003). Zircons from Syros, Cyclades, Greece - recrystallization and mobilization of zircon during high-pressure metamorphism. Journal of Petrology, 44, 1977-2002.

Trotet, F., Jolivet, L., \& Vidal, O. (2001a). Tectono-metamorphic evolution of Syros and Sifnos islands (Cyclades, Greece). Tectonophysics, 338, 179-206.

Trotet, F., Vidal, O., \& Jolivet, L. (2001b). Exhumation of Syros and Sifnos metamorphic rocks (Cyclades, Greece). New constraints on the PT paths. European Journal of Mineralogy, 13, 901-902.

Urai, J.L., Schuiling, R.D., \& Jansen, J.B.H. (1990). Alpine deformation on Naxos (Greece). Geological Society, London, Special Publications, 54, 509-522.

Uunk, B., Brouwer, F., ter Voorde, M., \& Wijbrans, J. (2018). Understanding phengite argon closure 
using single grain fusion age distributions in the Cycladic Blueschist Unit on Syros, Greece. Earth and Planetary Science Letters, 484, 192-203.

Vidal, O., de Andrade, V., Lewin, E., Munoz, M., Parra, T., \& Pascarelli, S. (2006). P-T deformation $-\mathrm{Fe} 3+/ \mathrm{Fe} 2+$ mapping at the thin section scale and comparison with XANES mapping: application to a garnet - bearing metapelite from the Sambagawa metamorphic belt (Japan). Journal of Metamorphic Geology, 24(7), 669-683.

Warren, C.J., \& Waters, D.J. (2006). Oxidized eclogites and garnet-blueschists from Oman: P-T path modeling in the NCFMASHO system. Journal of Metamorphic Geology, 24, 783-802.

Waters, D. J., \& Martin, H. N. (1996). The garnet-Cpx-phengite barometer. Recommended Calibration and Calculation Method, 1 .

Whitney, D. L., \& Evans, B. W. (2010). Abbreviations for names of rock-forming minerals. American mineralogist, 95(1), 185-187.

\section{SUPPORTING INFORMATION}

Additional Supporting Information may be found online in the supporting information tab for this article.

Figure S1. Garnet equilibrium modelling using the program GRTMOD (Lanari et al., 2017).

\section{Figure captions}

Figure 1: Overview of previously proposed $P-T$ paths for the Cycladic Blueschist Unit of Syros after a) Trotet et al. (2001b), b) Schumacher et al. (2008), c) Lister and Forster (2016). Mineral abbreviations are after Whitney and Evans (2010). Facies: AEBS, albite epidote blueschist; AM, amphibolite; EA, epidote-amphibolite; EB, epidote-blueschist; EC, eclogite; GS, greenschist; LB, lawsonite-blueschist; LC, lawsonite-chlorite; PA, pumpellyite-actinolite; PrAc, prehnite-actinolite; PrP, prehnite-pumpellyite; ZE, zeolite (Peacock, 1993).

Figure 2: Tectonic reconstructions of a N-S section of the Aegean domain highlighting the structure of the Hellenic subduction zone, the southward retreat of the slab with time and the evolution of the Cycladic Blueschist Unit from burial to final exhumation (after Jolivet and Brun, 2010). Abbreviations: NCDS, North Cycladic Detachment System; PND, Paros-Naxos Detachment, WCDS, West Cycladic Detachment System, NAF, North Anatolian Fault. 
Figure 3: Geological and metamorphic maps of Syros and associated cross-sections showing the large-scale structure of Syros (after Laurent et al. 2016). Location of samples and RSCM metamorphic peak temperature are shown on the metamorphic map.

Figure 4: Thin-section pictures of typical textures and mineralogical assemblages of analysed samples for thermobarometry and thermodynamic modelling.

Figure 5: Outcrop and sample description of SY1401 (Kampos Subunit). a) The Kastri Shear Zone, in which a strong gradient of deformation and retrogression is observed from eclogite- to greenschistfacies rocks. b, c, d) Decreasing scale pictures from outcrop to sample SY1401. Pictures b and c show stretched eclogites preserving a pillow-lava breccia structure and picture d corresponds to SY1401 before sampling.

Figure 6: Petrography of sample SY1401. a) Thin section photography showing the location of the mapped area. The white arrow shows incipient top-to-the east shear deformation. b) BSE image of the mapped area. c) Map of the minerals (obtained from the classification of the X-ray maps). d) Schematic representation of the mapped area with the distinct petro-textural domains and their estimated proportion in the sample.

Figure 7: X-Ray compositional map of SY1401. a, b, c, d) Composition of the garnet is zoned from core to rim. e) Composition of white mica defines four distinct groups in the map. f) Composition of clinopyroxene.

Figure 8: Petrography of sample SY1460. a) BSE image of a drilled rock-section of SY1460 locating the mapped area. b) BSE image of the mapped area. c) Map of the minerals (obtained from the classification of the X-ray maps). d) Schematic representation of the mapped area with the distinct petro-textural domains and their estimated proportion in the sample.

Figure 9: X-Ray compositional map of SY1460. a, b, c, d) Composition of the garnet is zoned from core to rim. e) White mica defines two phengite compositions. f) Composition of clinopyroxene.

Figure 10: Petrography of sample SY1407. a) BSE image of a drilled rock-section of SY1407 locating the mapped area. b) BSE image of the mapped area. c) Map of the minerals (obtained from the classification of the X-ray maps). d) Schematic representation of the mapped area with the distinct petro-textural domains and their estimated proportion in the sample. 
Figure 11: X-Ray compositional map of SY1407. a, b, c, d) Composition of the garnet is zoned from core to rim. e) White mica corresponds mainly to paragonite with only few phengite.

Figure 12: Petrography of sample SY1418. a) BSE image of a drilled rock-section of SY1418 locating the mapped area. b) BSE image of the mapped area. c) Map of the minerals (obtained from the classification of the X-ray maps). d) Schematic representation of the mapped area with the distinct petro-textural domains and their estimated proportion in the sample.

Figure 13: X-Ray compositional map of SY1418. a, b, c, d) Composition of the garnet is zoned from core to rim. e) White mica composition corresponds to phengite.

Figure 14: $P-T$ map calculated using the garnet-omphacite thermometer of Ravna (2000) together with the garnet-omphacite-phengite barometer of Waters and Martin (1996) (from XMAPTOOLS).

Figure 15: Garnet equilibrium modelling using the program GRTMOD (Lanari et al., 2017). Results are calculated using the thermodynamic database JUN92.bs and both measured bulk rock composition (WR, square) and local bulk compositions (LB, circle) considering or not $\mathrm{MnO}$ (dark vs. light blue colour). Solid lines are the error bars on the optimal $P-T$ conditions (see text). Numbers refer to the residual for each growth stage (core / rim or core / mantle / rim). Raman peak temperature estimates (RSCM-T) are represented in grey ( $\sigma$ weighted error) for samples of the same subunit.

Figure 16: P-T isochemical phase diagrams of SY1401 showing the good consistency between the predicted mineral assemblage in equilibrium for the two events of garnet growth and the mineral assemblage observed in the corresponding textural domain of the compositional map. Note that no consistency is observed for the second stage of rim garnet growth using the fractionated WR composition. Abbreviations: LB, Local Bulk; WR, Bulk Rock.

Figure 17: $P$-T path of the Cycladic Blueschist Unit on Syros. a) RSCM peak temperatures and results of empirical thermobarometry. b) Thermodynamic modelling of garnet growth. c) Compiled $P-T$ constraints for the CBU on Syros, Sifnos, Tinos and Andros islands. d) Proposed $P-T$ path for the CBU on Syros. 
Table 1: Bulk rock (WR) and local bulk (LB) compositions used for thermodynamic modeling.

\begin{tabular}{|c|c|c|c|c|c|c|c|c|}
\hline & \multicolumn{2}{|c|}{ SY1401 } & \multicolumn{2}{|c|}{ SY1460 } & \multicolumn{2}{|c|}{ SY1407 } & \multicolumn{2}{|c|}{ SY1418 } \\
\hline & $W R$ & $L B$ & $W R$ & $L B$ & $W R$ & $L B$ & $W R$ & $L B$ \\
\hline $\mathrm{SiO}_{2}$ & 52.64 & 51.54 & 50.76 & 51.34 & 67.39 & 65.61 & 48.52 & 49.75 \\
\hline $\mathrm{TiO}_{2}$ & 0.69 & 0.44 & 0.78 & 0.90 & 0.37 & 0.48 & 2.51 & 1.65 \\
\hline $\mathrm{Al}_{2} \mathrm{O}_{3}$ & 13.97 & 16.45 & 14.11 & 15.63 & 14.21 & 15.94 & 14.28 & 13.20 \\
\hline $\mathrm{FeO}$ & 8.15 & 9.42 & 6.29 & 7.48 & 4.71 & 4.61 & 15.58 & 17.63 \\
\hline $\mathrm{MnO}$ & 0.17 & 0.22 & 0.12 & 0.21 & 0.10 & 0.25 & 0.24 & 0.54 \\
\hline $\mathrm{MgO}$ & 5.21 & 5.06 & 5.76 & 5.13 & 2.42 & 1.62 & 6.04 & 4.43 \\
\hline $\mathrm{CaO}$ & 10.39 & 9.72 & 9.25 & 8.04 & 2.78 & 1.84 & 5.59 & 4.97 \\
\hline $\mathrm{Na}_{2} \mathrm{O}$ & 4.67 & 4.23 & 5.51 & 5.29 & 4.04 & 4.52 & 3.28 & 3.20 \\
\hline $\mathrm{K}_{2} \mathrm{O}$ & 1.70 & 1.85 & 2.50 & 2.47 & 0.53 & 0.21 & 0.16 & 0.08 \\
\hline Total & 97.57 & 98.93 & 95.08 & 96.49 & 96.55 & 95.09 & 96.20 & 95.46 \\
\hline
\end{tabular}


Table 2: RSCM peak temperature results. For each sample, the total number of measured Raman spectra (n) is shown together with the mean calculated temperature and the mean R2 ratio. The associated standard deviation (SD), related to the intra-sample heterogeneity, is also indicated. Peak temperature results are also represented on the Figure 2.

\begin{tabular}{|c|c|c|c|c|c|c|}
\hline \multirow{2}{*}{ Sample } & \multirow{2}{*}{$\mathbf{n}$} & \multicolumn{2}{|c|}{$\mathbf{R 2}$} & \multicolumn{3}{|c|}{$\mathbf{T}\left({ }^{\circ} \mathbf{C}\right)$} \\
\hline & & Mean & $S D$ & Mean & $S D$ & $1 \sigma$ \\
\hline \multicolumn{7}{|c|}{ Posidonia Subunit } \\
\hline SY1601 & 11 & 0.34 & 0.06 & 489 & 26 & 7.9 \\
\hline SY1602 & 21 & 0.17 & 0.04 & 564 & 20 & 4.3 \\
\hline SY1603 & 14 & 0.18 & 0.04 & 561 & 18 & 4.8 \\
\hline SY1604 & 13 & 0.27 & 0.04 & 520 & 19 & 5.2 \\
\hline SY1608 & 23 & 0.21 & 0.04 & 546 & 18 & 3.7 \\
\hline SY1610a & 18 & 0.22 & 0.04 & 541 & 16 & 3.8 \\
\hline $\begin{array}{c}\text { Mean } \\
\text { RSCM-T }\end{array}$ & & & & 537 & 20 & \\
\hline \multicolumn{7}{|c|}{ Chroussa Subunit } \\
\hline SY1309 & 16 & 0.24 & 0.04 & 535 & 17 & 4.1 \\
\hline SY1491 & 13 & 0.24 & 0.05 & 536 & 21 & 5.7 \\
\hline SY14108 & 25 & 0.19 & 0.05 & 558 & 21 & 4.2 \\
\hline SY1504 & 22 & 0.15 & 0.04 & 573 & 19 & 4.0 \\
\hline SY1505 & 12 & 0.24 & 0.06 & 533 & 28 & 8.0 \\
\hline SY1506 & 21 & 0.35 & 0.04 & 485 & 16 & 3.5 \\
\hline SY1624 & 17 & 0.13 & 0.04 & 581 & 19 & 4.5 \\
\hline SY 1626 & 13 & 0.28 & 0.03 & 515 & 12 & 2.7 \\
\hline $\begin{array}{c}\text { Mean } \\
\text { RSCM-T }\end{array}$ & & & & 540 & 19 & \\
\hline \multicolumn{7}{|c|}{ Kampos Subunit } \\
\hline SY1486 & 18 & 0.29 & 0.03 & 510 & 13 & 3.1 \\
\hline SY14102 & 17 & 0.21 & 0.02 & 546 & 11 & 2.6 \\
\hline SY14103 & 23 & 0.18 & 0.05 & 561 & 21 & 4.4 \\
\hline SY1605 & 20 & 0.29 & 0.06 & 514 & 26 & 5.9 \\
\hline SY 1622 & 19 & 0.27 & 0.03 & 519 & 15 & 3.5 \\
\hline $\begin{array}{c}\text { Mean } \\
\text { RSCM-T }\end{array}$ & & & & 530 & 17 & \\
\hline
\end{tabular}


Table 3: Garnet compositions used for thermodynamic modelling.

\section{SY1401}

SY1460

SY1407

SY1418

Grt core Grt mantle Grt rim Grt core Grt rim Grt core Grt mantle Grt rim Grt core Grt rim

\begin{tabular}{|l|l|l|l|l|l|l|l|l|l|l|}
$\mathrm{SiO}_{2}$ & 38.57 & 38.70 & 39.35 & 37.26 & 37.86 & 35.65 & 35.42 & 35.85 & 36.70 & 37.81 \\
\hline
\end{tabular}

\begin{tabular}{|l|l|l|l|l|l|l|l|l|l|l|}
$\mathrm{TiO}_{2}$ & 21.44 & 21.50 & 22.04 & 22.08 & 22.91 & 22.01 & 21.35 & 21.55 & 19.73 & 20.52 \\
\hline
\end{tabular}

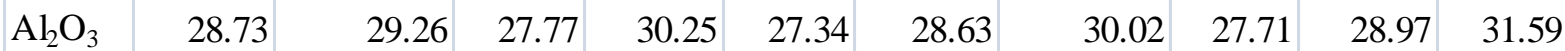

\begin{tabular}{|l|l|l|l|l|l|l|l|l|r|r|}
\hline $\mathrm{FeO}$ & 3.15 & 2.00 & 0.75 & 2.80 & 1.61 & 3.49 & 5.09 & 2.10 & 3.08 & 0.28 \\
\hline
\end{tabular}

\begin{tabular}{|l|r|r|r|r|r|r|r|r|r|r|}
\hline $\mathrm{MnO}$ & 1.58 & 1.73 & 2.56 & 1.45 & 2.21 & 1.00 & 1.17 & 1.46 & 1.02 & 2.18 \\
\hline
\end{tabular}

\begin{tabular}{|l|l|l|l|l|l|l|l|l|l|r|}
\hline $\mathrm{MgO}$ & 7.93 & 8.37 & 9.73 & 7.22 & 9.58 & 8.89 & 6.02 & 10.13 & 7.85 & 7.15 \\
\hline
\end{tabular}

\begin{tabular}{|l|l|l|l|l|l|l|l|l|r|r|}
\hline $\mathrm{CaO}$ & 0.01 & 0.01 & 0.01 & 0.04 & 0.03 & 0.03 & 0.03 & 0.03 & 0.02 & 0.02 \\
\hline
\end{tabular}

\begin{tabular}{|l|r|r|r|r|r|r|r|r|r|r|r|}
\hline $\mathrm{Na}_{2} \mathrm{O}$ & 0.01 & 0.01 & 0.01 & 0.00 & 0.00 & 0.01 & 0.01 & 0.01 & 0.04 & 0.03 \\
\hline
\end{tabular}

\begin{tabular}{|l|r|r|r|r|r|r|r|r|r|r|}
\hline $\mathrm{K}_{2} \mathrm{O}$ & 101.40 & 101.58 & 102.21 & 101.10 & 101.54 & 99.71 & 99.11 & 98.84 & 97.41 & 99.58 \\
\hline
\end{tabular}

Atom site distribution (12 anhydrous-oxygen basis)

\begin{tabular}{|c|c|c|c|c|c|c|c|c|c|c|}
\hline $\mathrm{Si}(\mathrm{O} / \mathrm{T})$ & 3.03 & 3.03 & 3.03 & 2.96 & 2.95 & 2.89 & 2.91 & 2.91 & 3.03 & 3.03 \\
\hline $\operatorname{Al}(\mathrm{Y})$ & 1.99 & 1.98 & 2.00 & 2.06 & 2.10 & 2.10 & 2.06 & 2.06 & 1.92 & 1.94 \\
\hline $\mathrm{Fe}(\mathrm{X})$ & 1.89 & 1.92 & 1.79 & 2.01 & 1.78 & 1.94 & 2.06 & 1.88 & 2.00 & 2.12 \\
\hline $\operatorname{Mg}(X)$ & 0.18 & 0.20 & 0.29 & 0.17 & 0.26 & 0.12 & 0.14 & 0.18 & 0.13 & 0.26 \\
\hline $\operatorname{Mn}(X)$ & 0.21 & 0.13 & 0.05 & 0.19 & 0.11 & 0.24 & 0.35 & 0.14 & 0.22 & 0.02 \\
\hline $\mathrm{Ca}(\mathrm{X})$ & 0.67 & 0.70 & 0.80 & 0.61 & 0.80 & 0.77 & 0.53 & 0.88 & 0.70 & 0.61 \\
\hline Xalm & 0.64 & 0.65 & 0.61 & 0.67 & 0.61 & 0.63 & 0.67 & 0.61 & 0.66 & 0.70 \\
\hline Xprp & 0.06 & 0.07 & 0.10 & 0.06 & 0.09 & 0.04 & 0.05 & 0.06 & 0.04 & 0.09 \\
\hline Xsps & 0.07 & 0.04 & 0.02 & 0.06 & 0.04 & 0.08 & 0.11 & 0.05 & 0.07 & 0.01 \\
\hline Xgrs & 0.23 & 0.24 & 0.27 & 0.21 & 0.27 & 0.25 & 0.17 & 0.29 & 0.23 & \\
\hline
\end{tabular}

This article is protected by copyright. All rights reserved. 
Table 4: White mica compositions used for thermodynamic modelling.

SY1401

SY1460

SY1407

SY1418

\begin{tabular}{|l|l|l|l|l|l|l|l|l|} 
Ph 1 & Ph 2 & Ph 3 & Ph-Pg & Ph 1 & Ph 2 & Ph & Pg & Ph \\
\hline
\end{tabular}

\begin{tabular}{|l|r|r|r|r|r|r|r|r|r|}
\hline $\mathrm{SiO}_{2}$ & 53.52 & 51.97 & 46.27 & 46.36 & 55.74 & 51.37 & 49.48 & 45.86 & 48.45 \\
\hline
\end{tabular}

\begin{tabular}{|l|r|r|r|r|r|r|r|r|r|}
\hline $\mathrm{TiO}_{2}$ & 26.73 & 27.93 & 34.11 & 39.28 & 22.41 & 26.88 & 29.29 & 40.45 & 25.31 \\
\hline
\end{tabular}

\begin{tabular}{|l|l|l|l|l|l|l|l|l|r|}
\hline $\mathrm{Al}_{2} \mathrm{O}_{3}$ & 2.63 & 2.43 & 4.57 & 1.27 & 2.54 & 2.63 & 4.00 & 0.78 & 4.32 \\
\hline
\end{tabular}

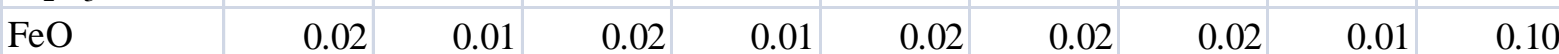

\begin{tabular}{|l|r|r|r|r|r|r|r|r|r|}
\hline $\mathrm{MnO}$ & 4.20 & 3.93 & 1.01 & 0.73 & 4.75 & 3.33 & 0.85 & 0.10 & 2.37 \\
\hline
\end{tabular}

\begin{tabular}{|l|l|l|l|l|l|l|l|l|r|}
\hline $\mathrm{MgO}$ & 0.02 & 0.02 & 0.02 & 0.03 & 0.02 & 0.02 & 0.07 & 0.10 & 0.03 \\
\hline
\end{tabular}

\begin{tabular}{|l|l|l|l|l|l|l|l|l|l|}
\hline $\mathrm{CaO}$ & 0.24 & 0.42 & 0.45 & 4.53 & 0.25 & 0.56 & 0.58 & 6.88 & 0.48 \\
\hline
\end{tabular}

\begin{tabular}{|l|r|r|r|r|r|r|r|r|r|}
$\mathrm{Na}_{2} \mathrm{O}$ & 9.84 & 9.49 & 9.53 & 1.86 & 10.75 & 10.22 & 8.14 & 0.56 & 8.74 \\
\hline
\end{tabular}

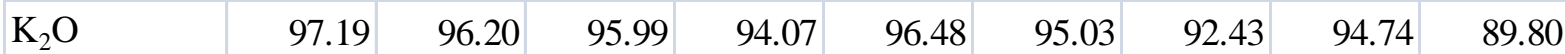

Atom site distribution (11 anhydrous-oxygen basis)

\begin{tabular}{|l|r|r|r|r|r|r|r|r|r|}
\hline $\mathrm{Si}(\mathrm{T} 1+\mathrm{T} 2)$ & 3.47 & 3.40 & 3.09 & 3.00 & 3.66 & 3.43 & 3.37 & 2.95 & 3.43 \\
\hline $\mathrm{Al}(\mathrm{T} 2)$ & 0.53 & 0.60 & 0.91 & 1.00 & 0.34 & 0.57 & 0.63 & 1.05 & 0.57 \\
\hline $\mathrm{V}(\mathrm{M} 1)$ & 0.94 & 0.93 & 0.88 & 0.87 & 1.00 & 0.98 & 0.96 & 0.94 & 0.95 \\
\hline $\mathrm{Mg}(\mathrm{M} 1)$ & 0.05 & 0.06 & 0.03 & 0.07 & 0.00 & 0.02 & 0.01 & 0.01 & 0.03 \\
\hline $\mathrm{Fe} 2+(\mathrm{M} 1)$ & 0.02 & 0.02 & 0.09 & 0.06 & 0.00 & 0.01 & 0.03 & 0.05 & 0.03 \\
\hline $\mathrm{Al}(\mathrm{M} 2+\mathrm{M} 3)$ & 1.52 & 1.56 & 1.77 & 1.99 & 1.39 & 1.55 & 1.73 & 2.01 & 1.55 \\
\hline $\mathrm{Mg}(\mathrm{M} 2+\mathrm{M} 3)$ & 0.36 & 0.33 & 0.07 & 0.00 & 0.47 & 0.31 & 0.07 & 0.00 & 0.22 \\
\hline $\mathrm{Fe}$ (M2+M3) & 0.13 & 0.11 & 0.17 & 0.00 & 0.14 & 0.14 & 0.20 & -0.01 & 0.23 \\
\hline $\mathrm{K}(\mathrm{A})$ & 0.81 & 0.79 & 0.81 & 0.15 & 0.90 & 0.87 & 0.71 & 0.05 & 0.79 \\
\hline $\mathrm{Na}(\mathrm{A})$ & 0.03 & 0.05 & 0.06 & 0.57 & 0.03 & 0.07 & 0.08 & 0.86 & 0.07 \\
\hline $\mathrm{V}(\mathrm{A})$ & 0.15 & 0.15 & 0.13 & 0.28 & 0.07 & 0.06 & 0.21 & 0.09 & 0.14 \\
\hline
\end{tabular}



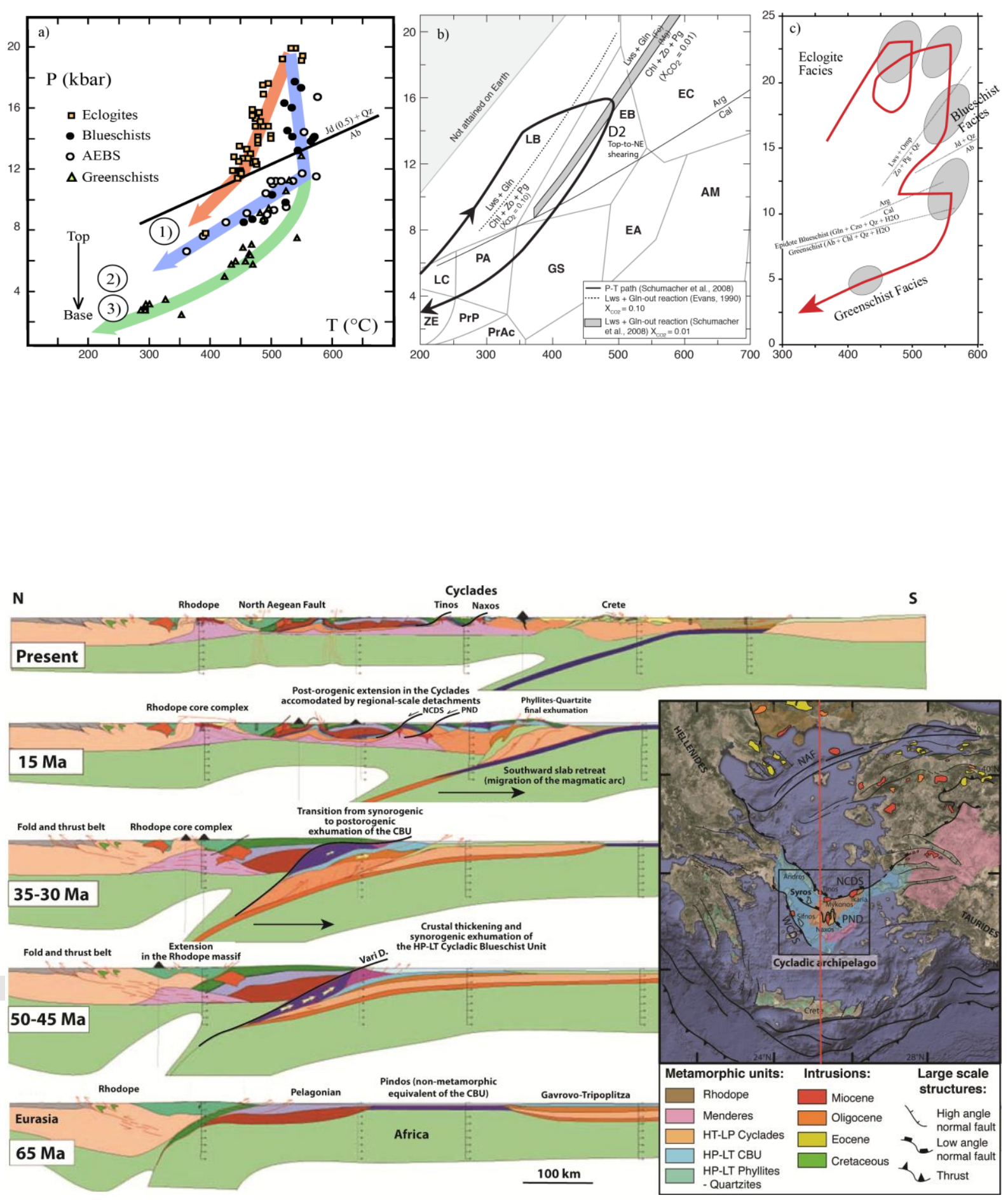

This article is protected by copyright. All rights reserved. 


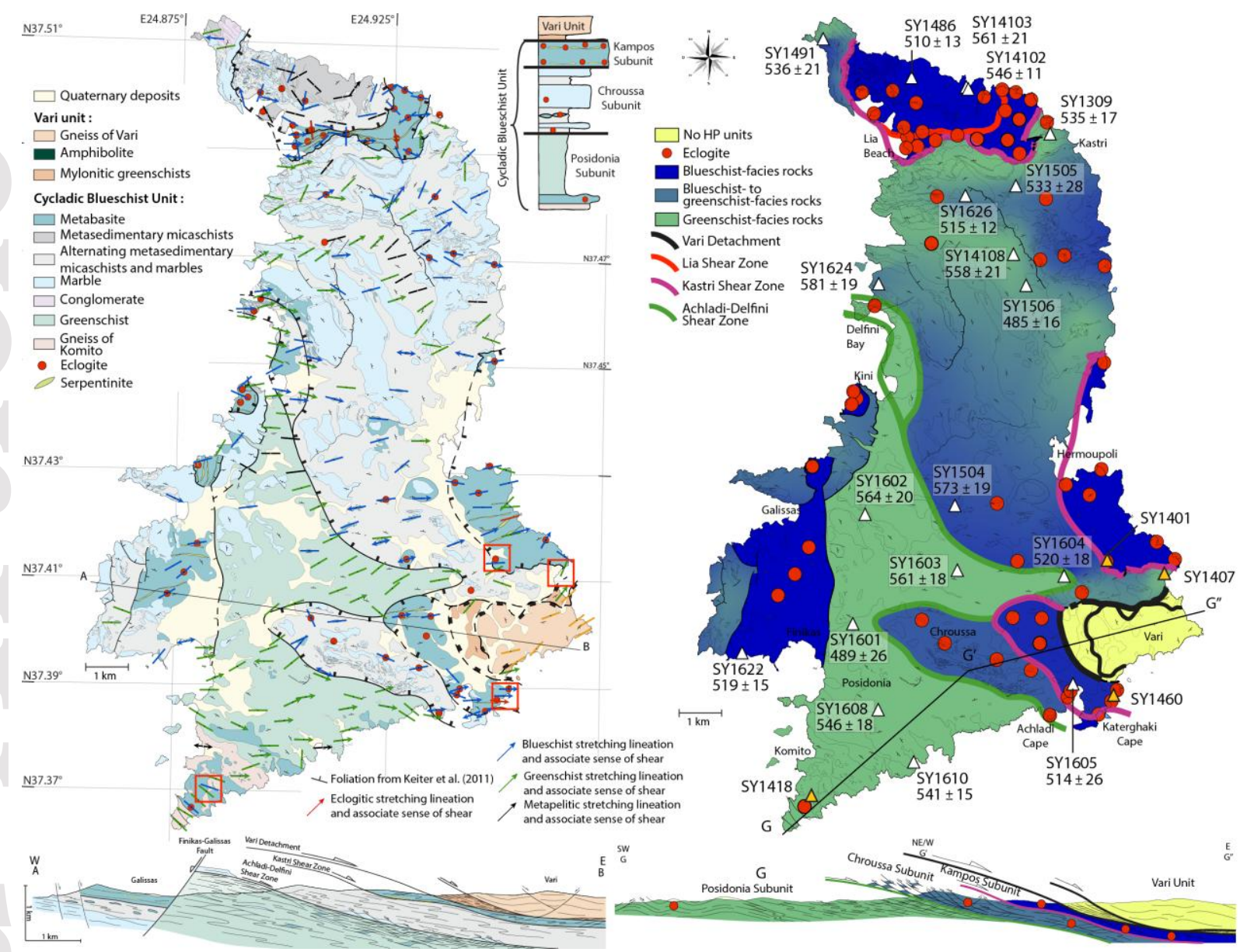

This article is protected by copyright. All rights reserved. 


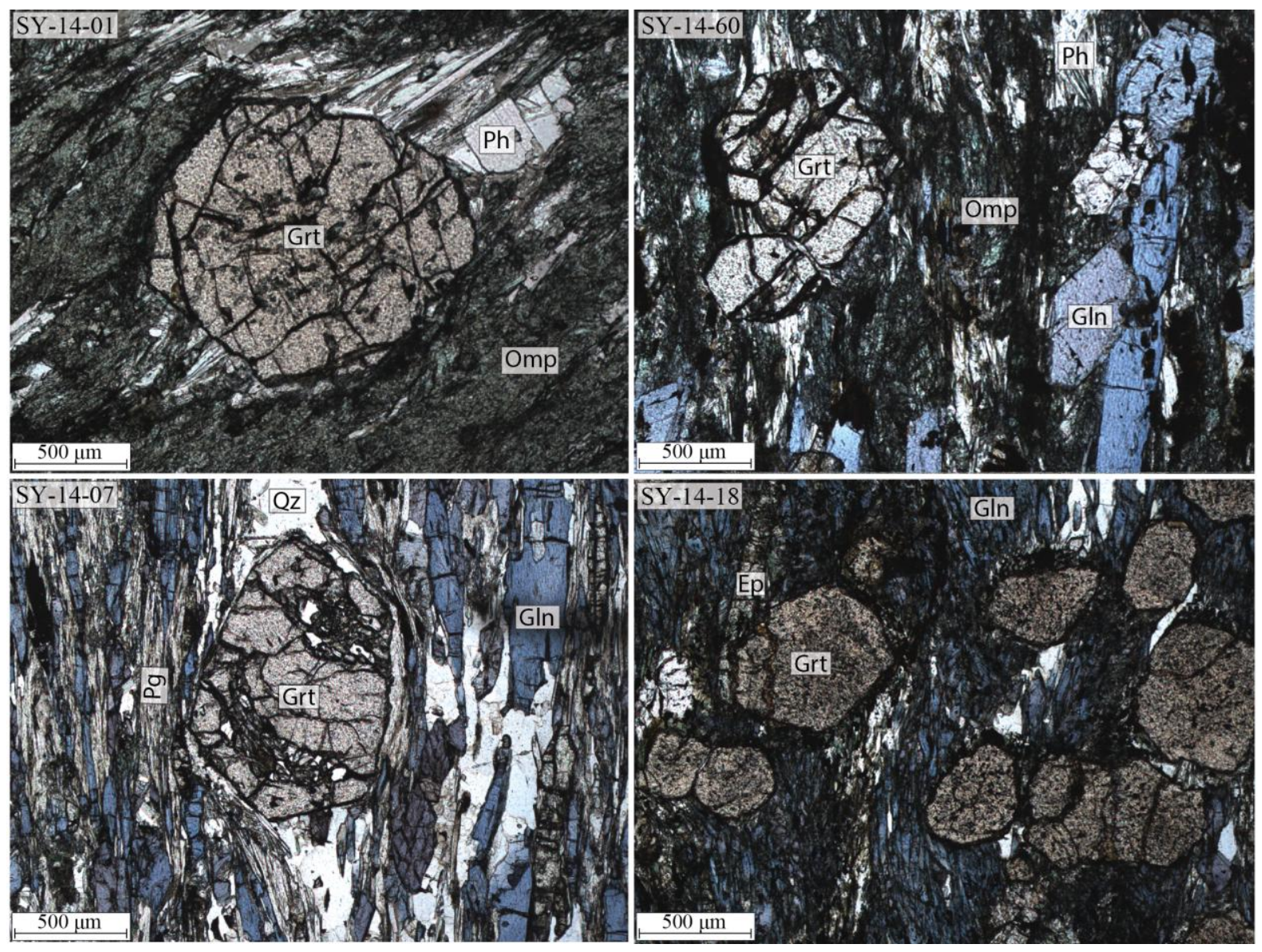

This article is protected by copyright. All rights reserved. 

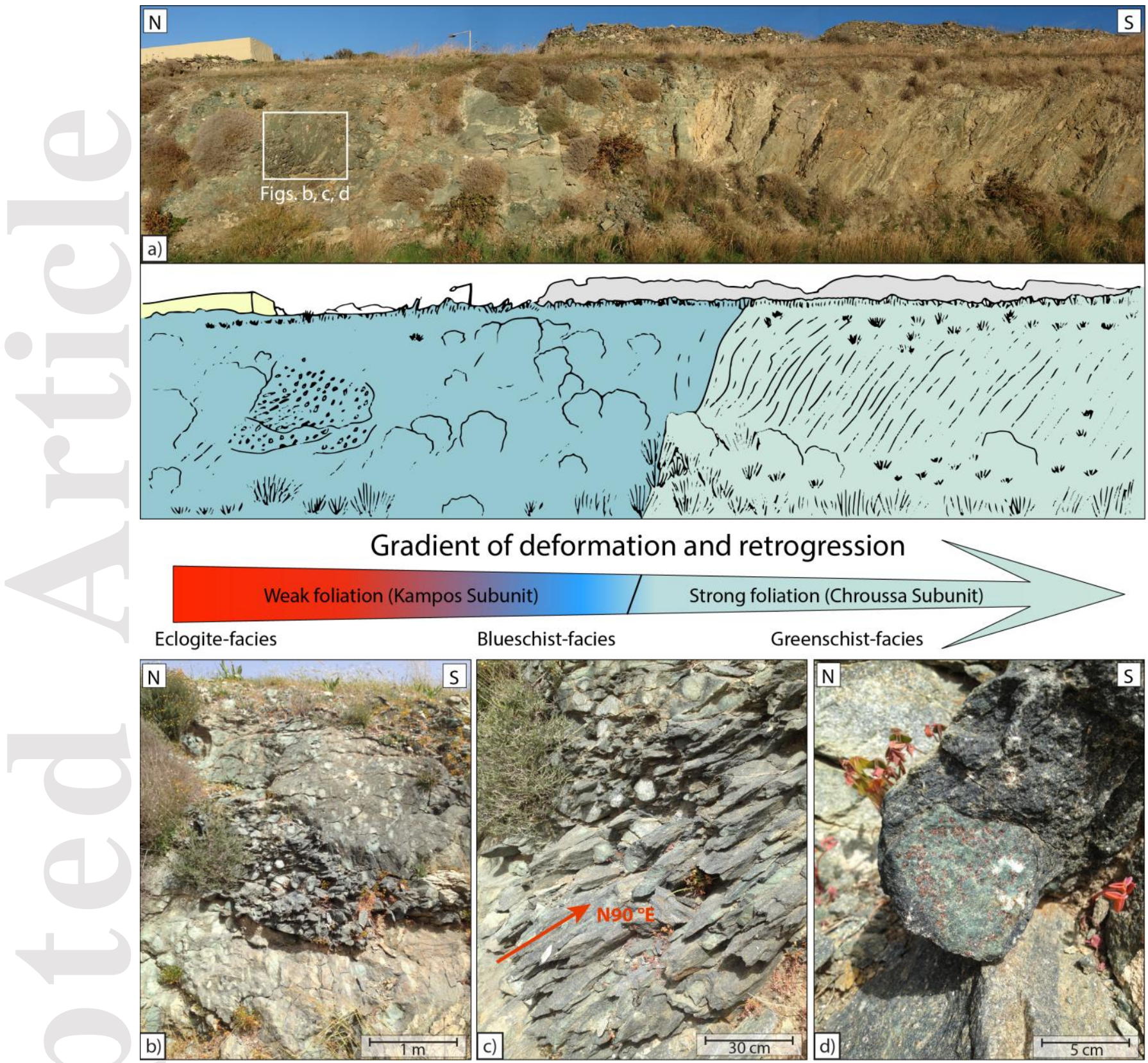

This article is protected by copyright. All rights reserved. 


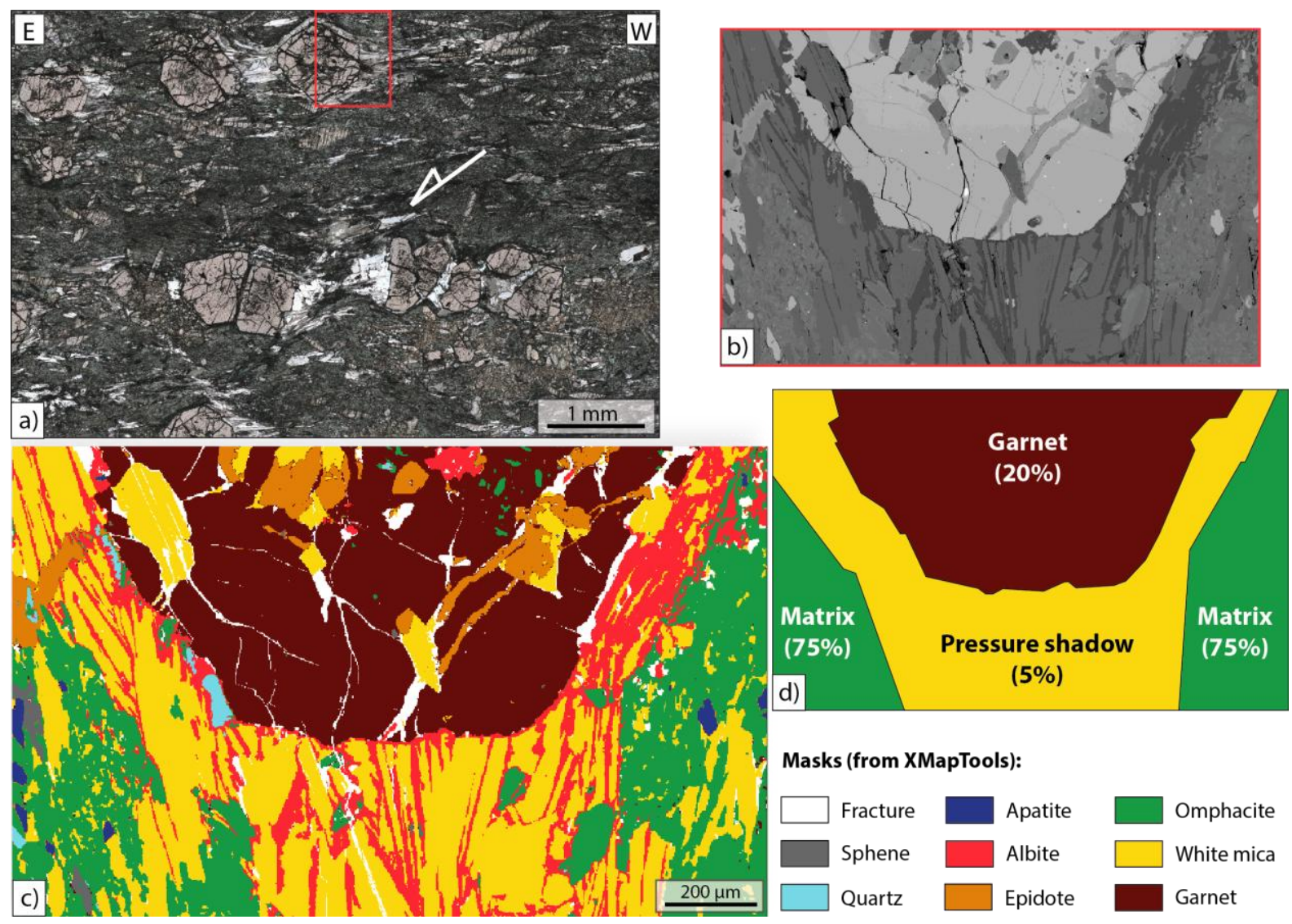

This article is protected by copyright. All rights reserved. 

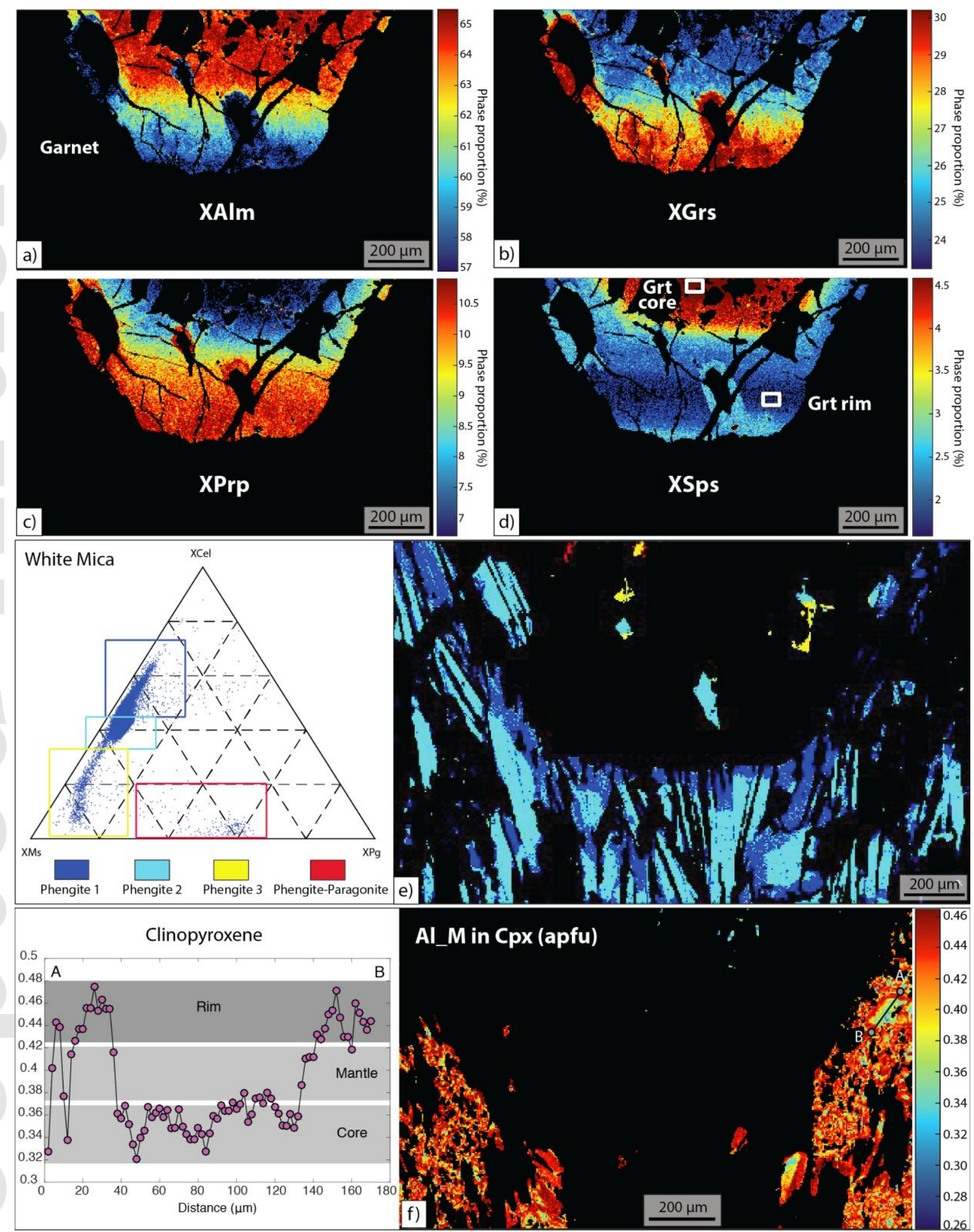

This article is protected by copyright. All rights reserved. 


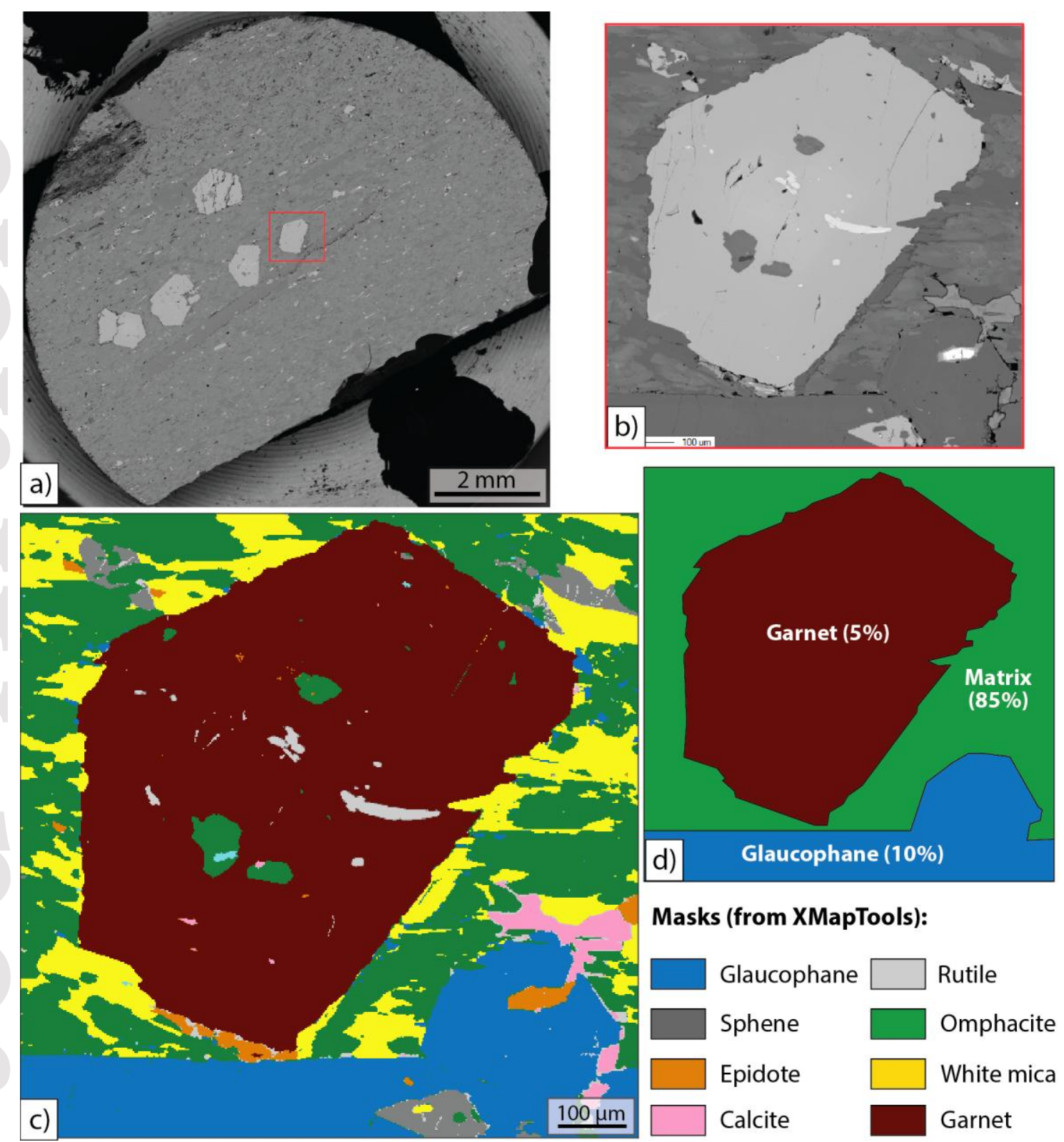

This article is protected by copyright. All rights reserved. 

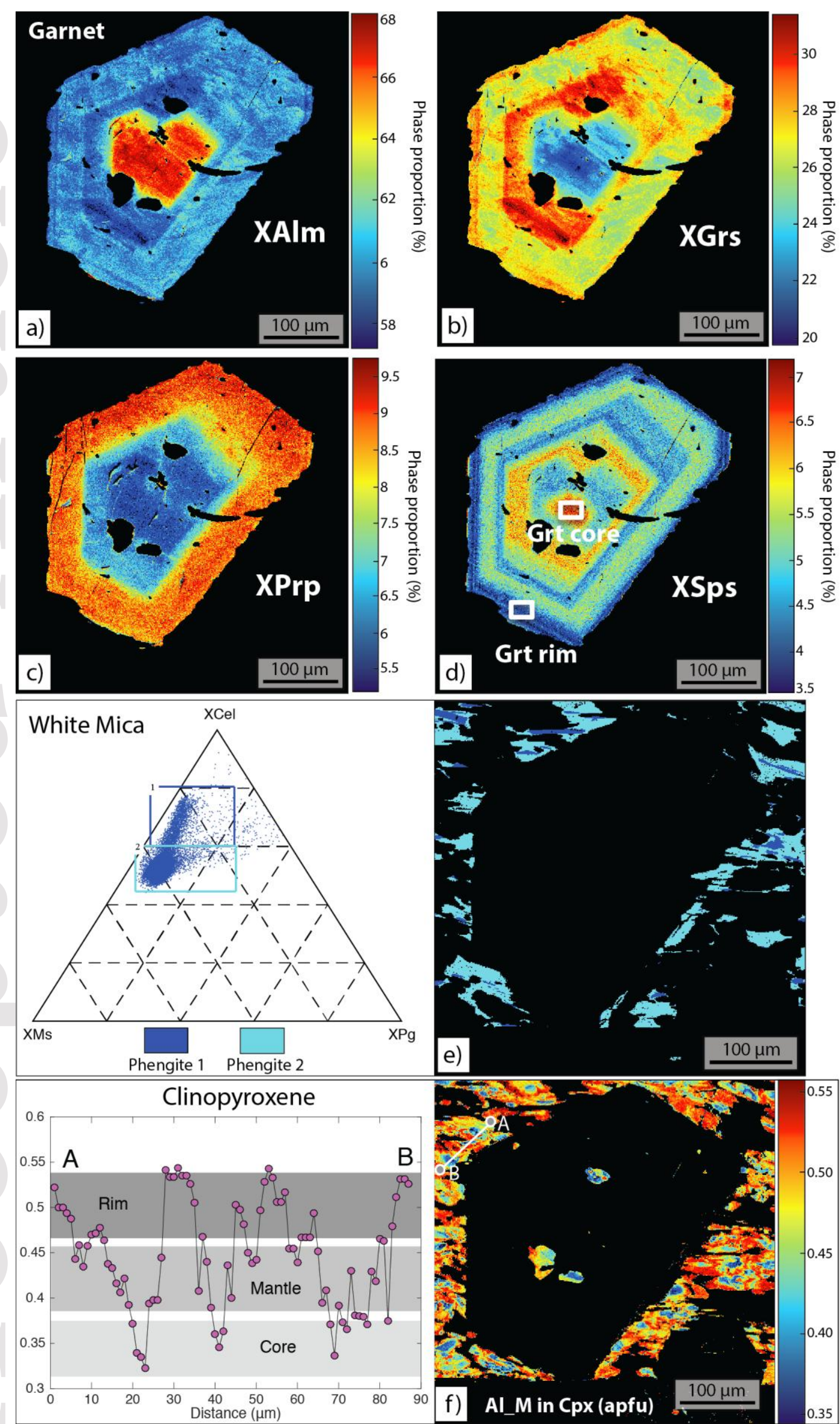

This article is protected by copyright. All rights reserved. 


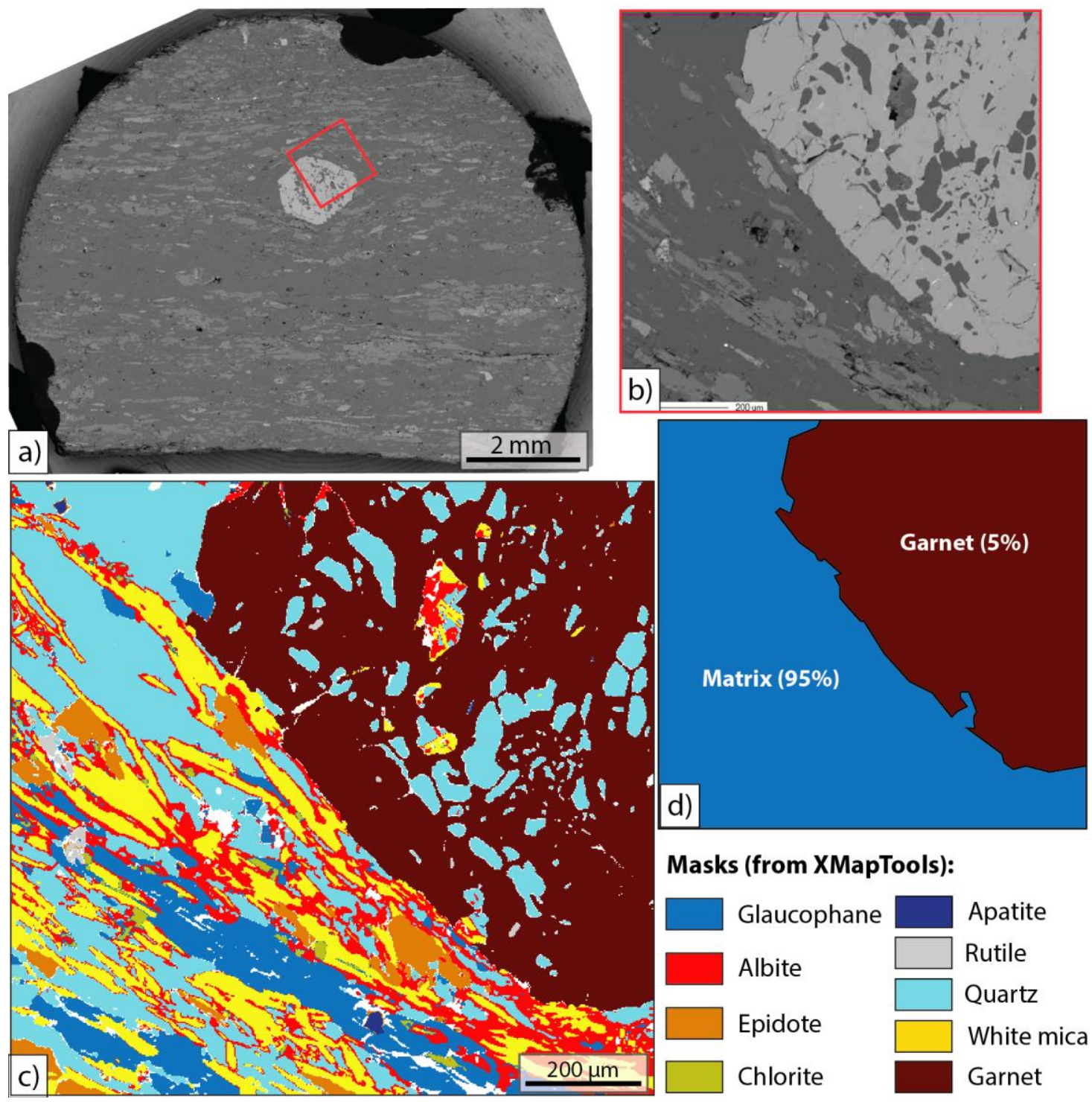

This article is protected by copyright. All rights reserved. 

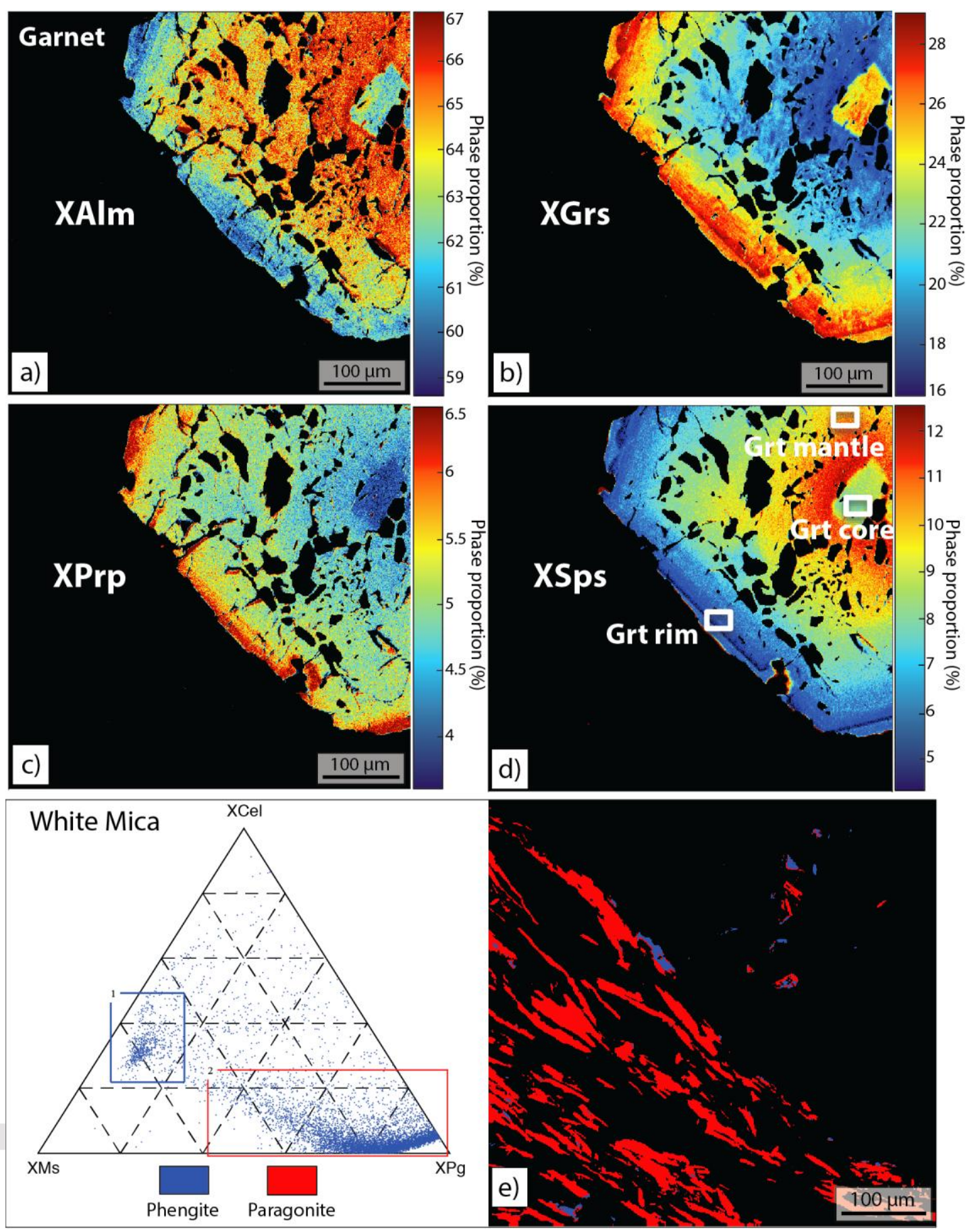

This article is protected by copyright. All rights reserved. 

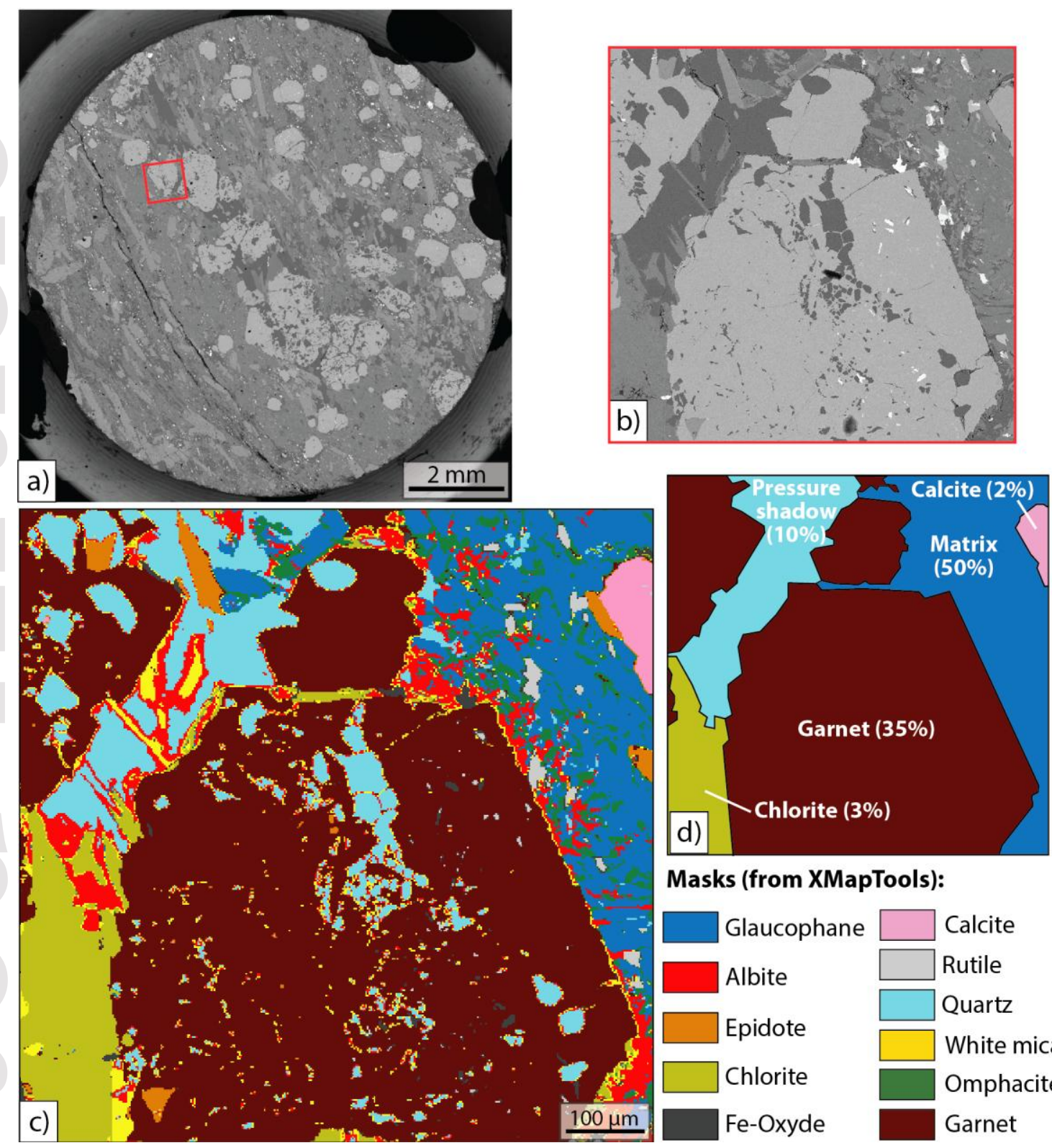

Masks (from XMapTools):

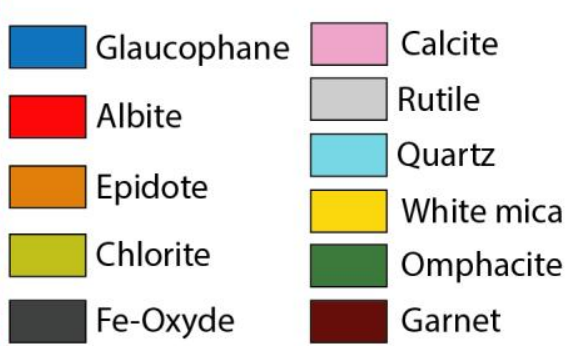




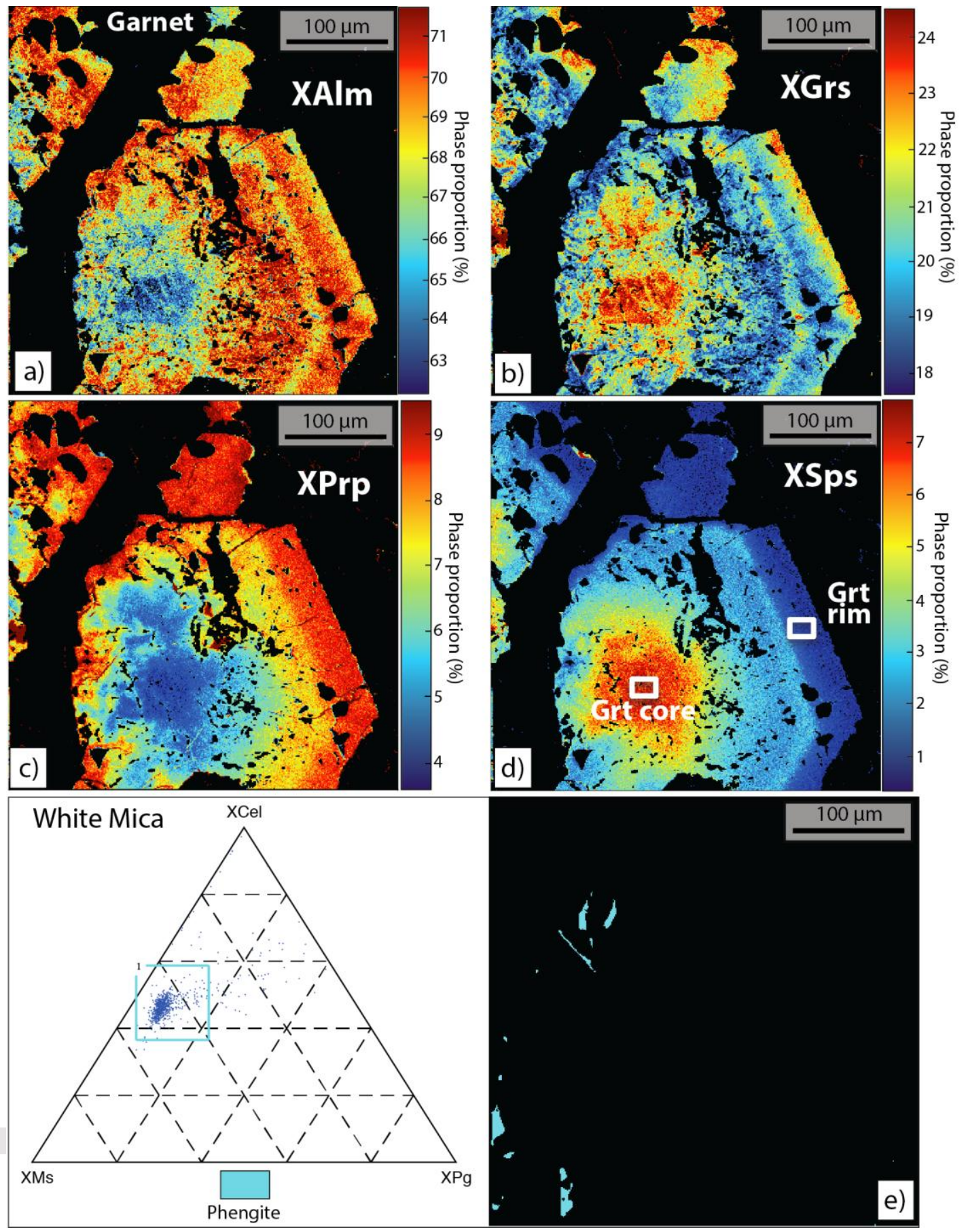

This article is protected by copyright. All rights reserved. 

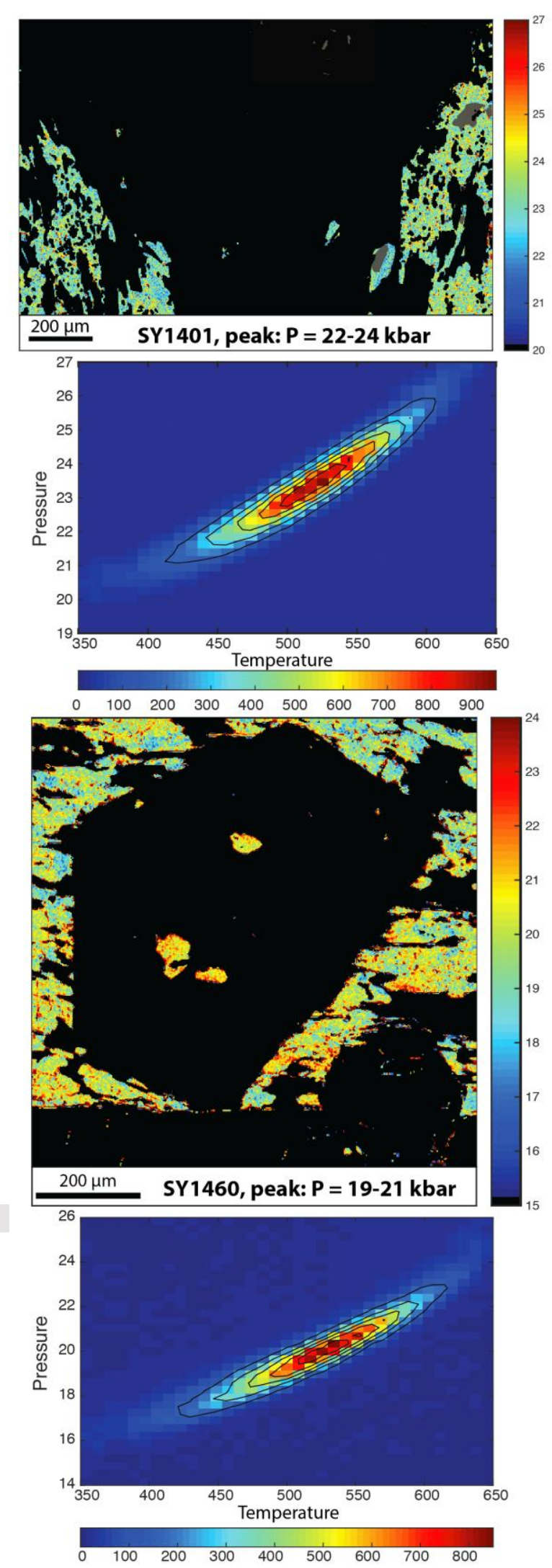
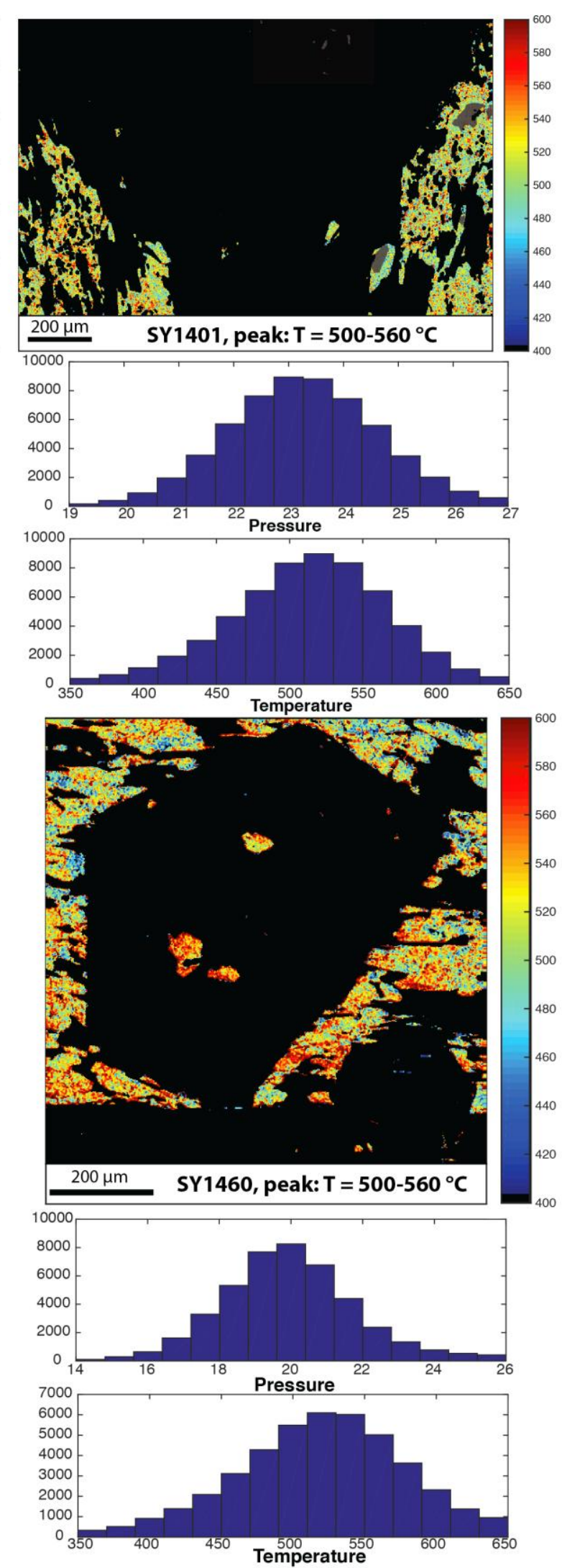

This article is protected by copyright. All rights reserved. 

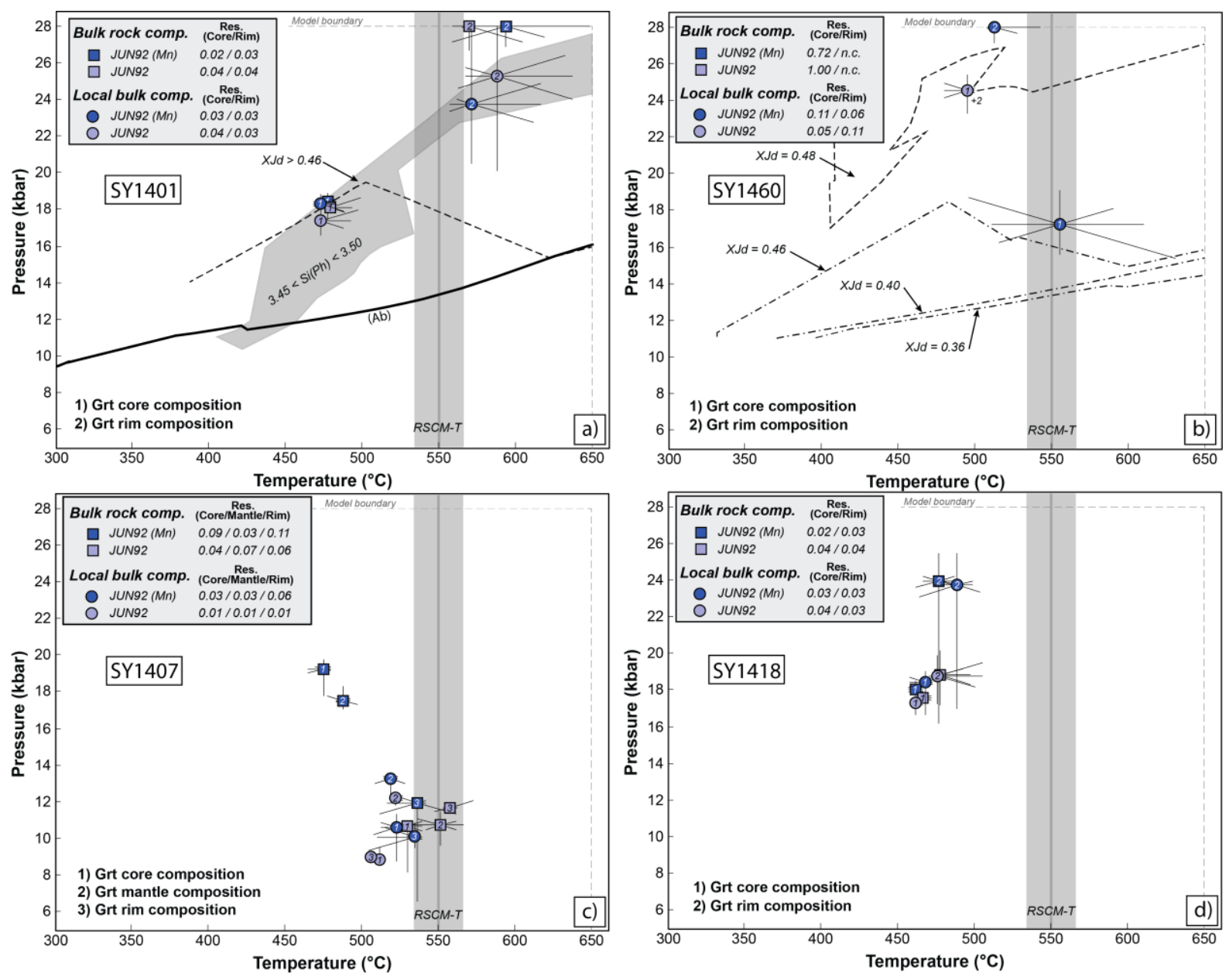

This article is protected by copyright. All rights reserved. 


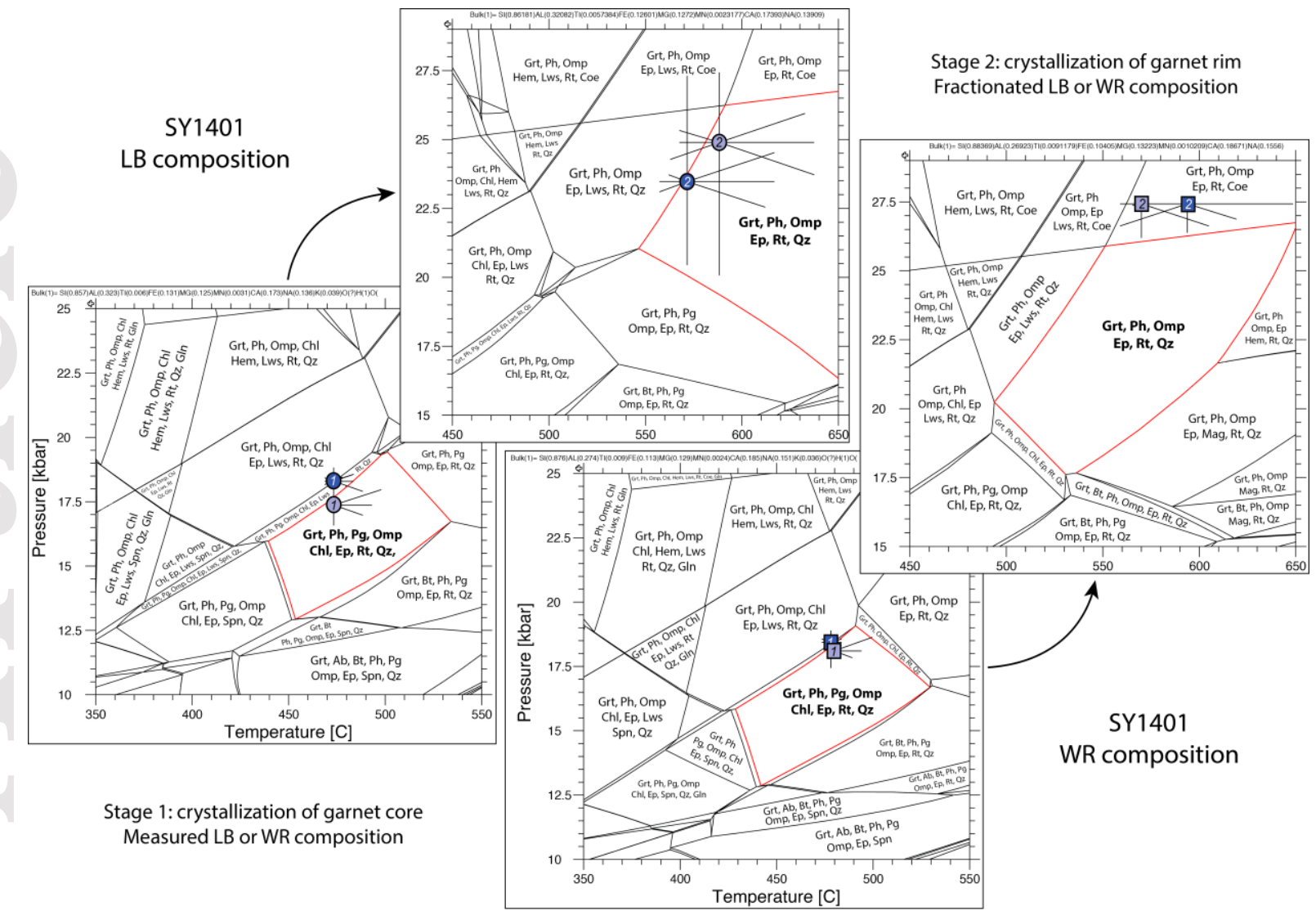

This article is protected by copyright. All rights reserved. 

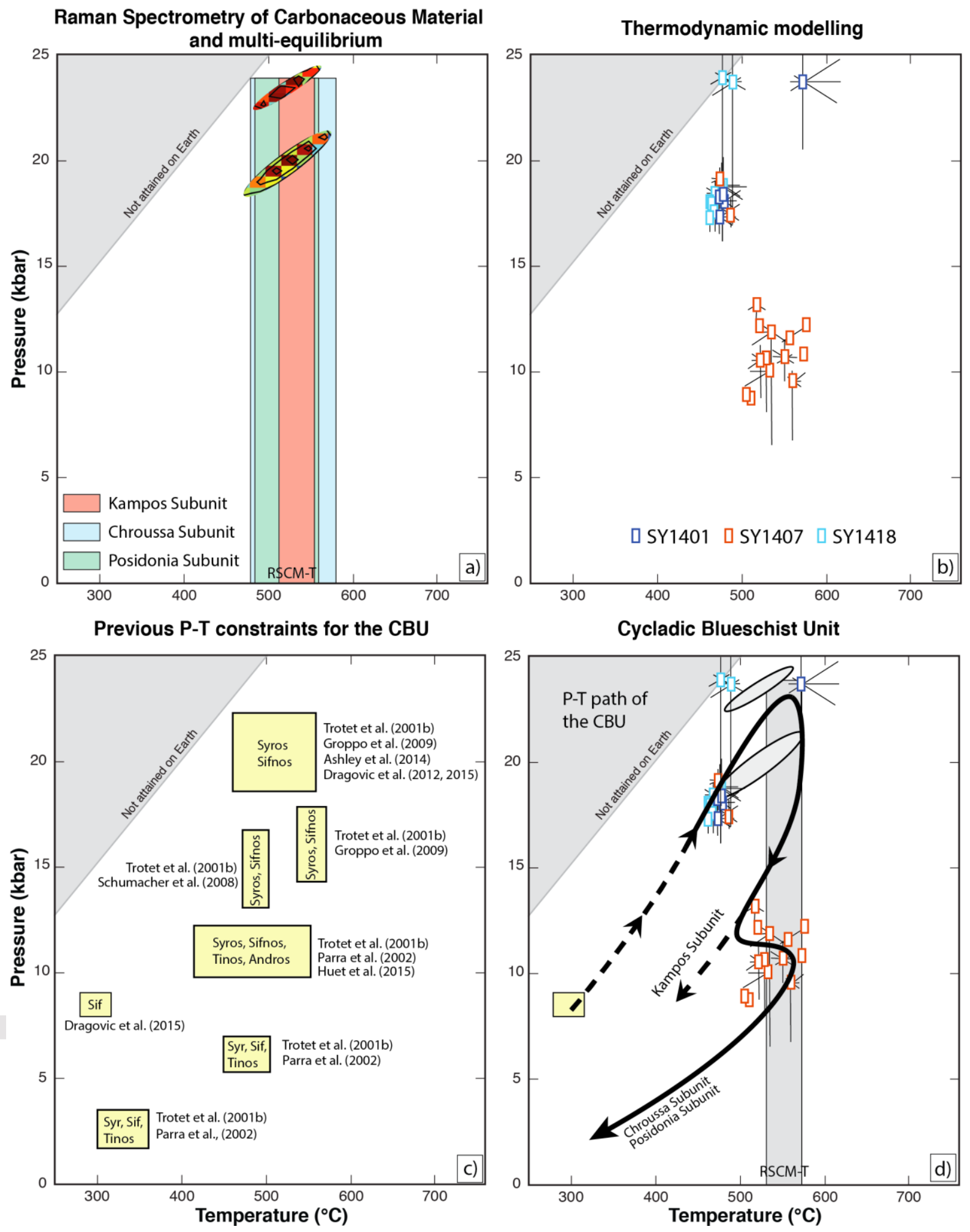

This article is protected by copyright. All rights reserved. 